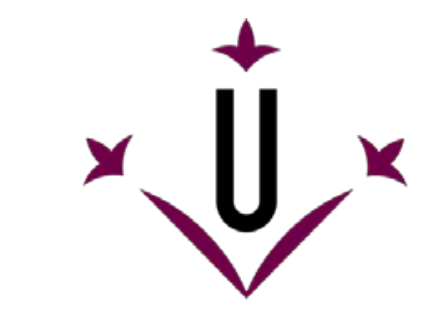

Universitat de Lleida

Document downloaded from:

http://hdl.handle.net/10459.1/64952

The final publication is available at:

https://doi.org/10.2135/cropsci2017.11.0676

Copyright

(c) Crop Science Society of America, 2018 
Publisher: AGRONOMY; Journal: CROPSCI:Crop Science; Copyright: Will notify... Volume: Will notify...; Issue: Will notify...; Manuscript: crop-2017-11-0676-ora; DOI: ; PII: $<$ txtPII $>$

TOC Head: ; Section Head: ; Article Type: ARTICLE

Crop Physiology \& Metabolism

\title{
Maize Grain Weight Sensitivity to Source-Sink Manipulations under a Wide Range of Field Conditions
}

\author{
Raziel A. Ordóñez, Roxana Savin, C. Mariano Cossani, and Gustavo A. Slafer*
}

R.A. Ordóñez, Dep. of Crop and Forest Sciences and AGROTECNIO (Center for Research in Agrotechnology), Univ. of Lleida, Av. Rovira Roure 191, 25198 Lleida, Spain, current address, Dep. of Agronomy, Iowa State Univ., Agronomy Hall, Ames, IA 50011-1010; R. Savin and G.A. Slafer, Dep. of Crop and Forest Sciences and AGROTECNIO (Center for Research in Agrotechnology), Univ. of Lleida, Av. Rovira Roure 191, 25198 Lleida, Spain; C.M. Cossani, Dep. of Crop and Forest Sciences and AGROTECNIO (Center for Research in Agrotechnology), Univ. of Lleida, Av. Rovira Roure 191, 25198 Lleida, Spain, current address, South Australian Research and Development Institute-SARDI, Waite Building 11a Hartley Grove, 5001 Adelaide, Australia; G.A. Slafer, ICREA, Catalonian Institution for Research and Advanced Studies, Spain. Received 13 Nov. 2017. Accepted 18 July 2018. *Corresponding author (slafer@pvcf.udl.cat). Assigned to Associate Editor Maria Otegui.

\begin{abstract}
Physiological causes for grain weight determination in maize (Zea mays L.) are not clear. Source-sink relationships during grain filling modulate grain weight, and there are controversies regarding the degree of source limitation that may exist during grain filling. We aimed to analyze likely causes of the responsiveness of maize grain weight to defoliation and degraining treatments imposed $15 \mathrm{~d}$ after silking, quantifying the responsiveness of grain weight to these source-sink manipulations in a large number of field conditions (52 background conditions in which source-sink manipulations were imposed). Grain weight was largely unresponsive to increases in source availability but was diminished by defoliations in six out of seven experiments. Interestingly, grain weight reductions due to defoliation were not hierarchical (grains from different positions along the ear responded similarly) and were not worsened by imposing a simultaneous heat stress. Heat affected the grain growth capacity directly, and indirect effects (through reducing source strength due to accelerated senescence) were not evident. The penalty imposed by heat was neither increased by defoliation nor diminished by degraining, and the reduction in grain weight was similar for grains with different potential size. Our study reinforced the concept that maize yield is limited by the sink strength during grain filling, even when grain weight may respond to reductions in the grain filling source-sink ratio.
\end{abstract}

Although yield is the product of the number of grains set per square meter and their average weight (Slafer, 2003; Borrás and Gambín, 2010), it is generally far better related to the former than to the latter (Borrás et al., 2004; Slafer et al., 2006). This general statement for grain crops naturally applies to maize (Zea mays L.) as well (Otegui, 1995; Chapman and Edmeades, 1999), because grain number has greater plasticity (i.e., it is more responsive to environmental changes) than grain weight (Sadras, 2007; Sadras and Slafer, 2012; Slafer et al., 2014). Even though grain number is the main yield determinant, grain weight is by no means invariable. In fact, large differences in yield can be normally observed for a similar number of harvested grains (Borrás et al., 2004).

It has been clearly established that variations in grain number are largely related to plant growth during the critical period of grain number determination, from approximately a couple of weeks before to a couple of weeks after silking (Edmeades and Daynard, 1979; Kiniry and Ritchie, 1985; Aluko and Fischer, 1988; Tollenaar et al., 1992; Otegui and Bonhomme, 1998; Andrade et al., 1999; Vega et al., 2001). On the other hand, physiological causes of grain weight determination are less clear. Part of this uncertainty may be because grain weight potential is initially set during floret growth and the early part of post-silking, when maximum grain volume 
Publisher: AGRONOMY; Journal: CROPSCI:Crop Science; Copyright: Will notify... Volume: Will notify...; Issue: Will notify...; Manuscript: crop-2017-11-0676-ora; DOI: ; PII: $<$ txtPII $>$

TOC Head: ; Section Head: ; Article Type: ARTICLE

is reached, and then there is a grain weight realization period when grains are effectively filled. The period of grain weight potential determination (c. $15 \mathrm{~d}$ before to $15 \mathrm{~d}$ after silking) overlaps strongly with the critical period of grain number determination (Borrás and Gambín, 2010). During this developmental period, several key bottlenecks for grain yield determination occur. First, the number of florets that will become fertile and pollinated (Kirby, 1988; Otegui, 1997; Cárcova et al., 2003), as well as the size of the ovaries of these florets, are established (Calderini et al., 1999a). Second, during the "lag phase" between ovule fertilization and the onset of the effective grain-filling period, the number of endosperm cells is determined (Brocklehurst, 1977; Reddy and Dynard, 1983). Both the ovary size and the number of endosperm cells, which might be related to kernel expansion early in development (Borrás and Westgate, 2006), largely determine the potential grain size. At the same time, both grain number and grain weight are affected by the amount of assimilates available per floret and/or grain during the critical period for grain number determination (Calderini et al., 1999b; Gambín et al., 2006; Ugarte et al., 2007; Borrás and Gambín, 2010; Ferrise et al., 2010; Hasan et al., 2011; Ferrante et al., 2012). Thus, potential grain weight is normally considered source limited - the larger the assimilate availability per floret or grain around flowering (before the onset of grain growth), the greater the potential size of the grain. For instance, artificial manipulations to reduce fruiting efficiency (the efficiency of converting plant growth around flowering into grains) by reducing the number of florets setting grains but not altering growth and partitioning around flowering, resulting in final grain size increases in both wheat (Triticum aestivum L.) (Calderini and Reynolds, 2000) and maize (Gambín et al., 2006).

Final grain weight depends on grain size potential, as well as on the realization of this potential during the effective grain-filling period. In wheat and barley (Hordeum vulgare L.), it is clear that grain growth during the effective grain-filling period is largely sink limited (Slafer and Savin, 1994; Richards, 1996; Dreccer et al., 1997; Calderini et al., 2006; Cartelle et al., 2006; Bingham et al., 2007; Pedró et al., 2011; Serrago et al., 2013). In maize, it is frequently accepted that the potential grain size is achieved if the crop does not go through "major limitations" in assimilate availability (Borrás and Westgate, 2006), and then grain growth would be sink limited during this period (Otegui et al., 1995; Maddonni et al., 1998; Gambín et al., 2008). However, if the crop goes through limitations in assimilate availability during the effective grain-filling period (e.g., reduced incoming solar radiation or accelerated senescence), the potential would not be realized, presumably due to source limitation during grain filling (Cerrudo et al., 2013). The controversies are supported by the statement raised long ago by Tollenaar and Daynard (1982), who pointed out that "a delicate balance exists between sink and source during the grain-filling period of maize and that disturbance of this balance can cause substantial yield reductions." A reflection of that delicate balance was provided by Borrás et al. (2004) when comparing the situation of maize with that of wheat and soybean [Glycine max (L.) Merr.]. The analysis of Borrás et al. (2004) showed that although in wheat grain weight only seldom responds to increases or reductions in assimilate availability per grain during grain filling (Slafer and Savin, 1994; Borrás et al., 2004), in maize it does not vary in response to increases (Kiniry et al., 1990; Borrás et al., 2003) while sharply decreasing with reductions in assimilate availability per grain during grain filling (Borrás et al., 2004). For instance, lack of source strength to fill the grains has also been claimed as the likely cause of grain weight reductions due to management practices like delaying sowing dates (Cirilo and Andrade, 1996). 
Publisher: AGRONOMY; Journal: CROPSCI:Crop Science; Copyright: Will notify... Volume: Will notify...; Issue: Will notify...; Manuscript: crop-2017-11-0676-ora; DOI: ; PII: $<$ txtPII $>$

TOC Head: ; Section Head: ; Article Type: ARTICLE

Maize research linked to source-sink limitations for grain growth was based on the analyses of the relationship between grain weight and plant growth per grain set during grain filling. Most experiments modified these variables through treatments such as sowing date, plant density, or $\mathrm{N}$ fertilization (Ahmadi et al., 1993; Maddonni et al., 1998). However, these treatments may not provide conclusive evidence, as they affect both source and sink strength. There have been studies in which more direct treatments were imposed on maize. Among them, studies conducted by Echarte et al. (2006), Sala et al. (2007), and Severini et al. (2011), defoliating or thinning plots after the onset of grain growth, are in line with the overall conclusion from the metaanalysis done by Borrás et al. (2004): although grain weight response to increases in resource availability was not consistent, it was quite sensitive to reductions in assimilate availability.

Future weather scenarios predict more frequent exposure to high temperatures (Lobell et al., 2011; Cairns et al., 2013), which would negatively affect yield through physiological mechanisms like accelerated leaf senescence (Badu Apraku et al., 1983; De la Haba et al., 2014). The negative effect of high temperatures over grain weight might be dual - there can be a direct effect on the capacity of grains to grow (Rattalino Edreira et al., 2014) or an indirect effect through reducing source availability by accelerating senescence. The relevance of this indirect effect can be related to the degree of source limitation for grain filling. To the best of our knowledge, no experiments have been conducted in maize in which high-temperature treatments had been combined with source-sink manipulations during the effective grain-filling period. Slafer and Miralles (1992) reported that the effects of heat stress on wheat grain weight were exclusively direct on the capacity of grains to grow (in line with Jenner et al., 1991). Although heat stress did accelerate senescence as well, the reduction in grain weight was not reversed (nor even alleviated) by increasing the availability of assimilates per grain in heated plots (Slafer and Miralles, 1992). As the source-sink balance determining grain growth during the effective grainfilling period seems more delicate in maize than in wheat (Borrás et al., 2004), extrapolations from one species to another may not be trustworthy, and direct experimentation is required.

A treatment extensively used in wheat and barley studies is the removal of half of the population of grains after the potential grain size is fixed (Slafer and Savin, 1994; Calderini et al., 2006). The concept is to observe how the remaining grains grow under reduced competition, compared with an untreated control. If growth of the grains was limited only by the source of assimilates, grain weight should increase in proportion to the reduced competition. This treatment would be critical in combination with heat stress to conclude whether any heat effects on grain growth are direct (on the capacity of grains to grow) or indirect (through reducing source strength by accelerating senescence). In maize, this treatment is challenging, as grains are covered by husks (a whorl of modified ear leaves). Jones and Simmons (1983) and Kiniry et al. (1990) attempted a direct manipulation of sink strength by simply cutting the ear and removing the apical half at different days after silking. Due to the nature of the distribution of grains of different size potential within the ear, they removed the least competitive grains, generating a mild treatment, and the degree of source limitation of central and apical grains could not be analyzed. This could be a problem, as the grains of the tip of the ear may be far more limited by the source to fill them than by their inherent capacity to grow, a conclusion derived from a sophisticated study in which grains from the apical part of the ear cultured in vitro were much heavier than those from field-grown ears (Hanft et al., 1986). Gambín et al. (2007) applied a treatment eliminating (by using a frame with needles) few grains from adjacent rows $15 \mathrm{~d}$ after 
Publisher: AGRONOMY; Journal: CROPSCI:Crop Science; Copyright: Will notify... Volume: Will notify...; Issue: Will notify...; Manuscript: crop-2017-11-0676-ora; DOI: ; PII: $<$ txtPII $>$

TOC Head: ; Section Head: ; Article Type: ARTICLE

silking, to avoid effects on grain size potential, to test whether final grain size in maize might be limited by their capacity to expand. Tollenaar and Daynard (1978a) and Gambín et al. (2007) proved the feasibility of degraining treatments in maize, but, as mentioned above, their analysis was not focused on the effects of source-sink relationship on yield components.

The main objective of this study was to quantify and to analyze likely causes of the responsiveness of maize grain weight to defoliation and degraining treatments imposed at the beginning of the effective grain-filling period. These source-sink manipulations were imposed under a wide range of field conditions, like $\mathrm{N}$ fertilization regimes, hybrids, and heat stress treatments during grain filling.

\section{MATERIALS AND METHODS}

\section{General Conditions}

Seven field experiments were conducted in the province of Lleida (Catalonia, northeastern Spain) on farmer's paddocks. In the first two growing seasons (2009 and 2010), experiments were located at two sites differing in altitude: (i) close to Algerri $\left(41^{\circ} 47^{\prime} 41^{\prime \prime} \mathrm{N}, 0^{\circ} 38^{\prime} 52^{\prime \prime} \mathrm{E}\right.$; 230 $\mathrm{m}$ asl), a relatively warm location within the plain of the province and part of the valley of the Ebro River (one sowing date in the first year and two sowing dates with 31 days of difference in the second year; Exp. 1, 3, and 4); and (ii) close to La Seu d'Urgell $\left(42^{\circ} 20^{\prime} 45^{\prime \prime} \mathrm{N}, 1^{\circ} 25^{\prime} 52^{\prime \prime} \mathrm{E}\right.$; $730 \mathrm{~m}$ asl), a relatively cool valley in the middle of the Pyrenees (Exp. 2 and 5). In the last two growing seasons (2011 and 2012), experiments were conducted only close to Algerri (Exp. 6 and 7) (Table 1).

Experiments were sown within the usual sowing dates for the region within each location, and at a plant density within the range considered optimum for our production system (Table 1). All experiments were maintained free of water stress through periodic sprinkler irrigations (Exp. 1, 2, and 5) or drip irrigation systems (Exp. 4, 6, and 7), maintaining soil moisture close to field capacity throughout the growing season. Weeds, pest, and diseases were prevented or controlled by spraying recommended herbicides, insecticides, and fungicides at suggested rates.

Main plots in each site were eight rows wide (0.70-0.75 $\mathrm{m}$ of inter-row spacing, and 20-40 $\mathrm{m}$ long, depending on the experiment). Genotypes were two hybrids used across the first five experiments (Exp. 1-5), and only one used in Exp. 6 and 7 (in which case, the number of $\mathrm{N}$ fertilization regimes was increased) (Table 1). Experimental design was always a split plot with main plots randomized in three blocks. In Exp. 1 and 3, main plots were assigned to the hybrids (Lapopi and PR31N28), the subplots were assigned to $\mathrm{N}$ availabilities, the sub-subplots were assigned to temperature regimes, and the source-sink manipulations were subplots within temperature regimes. In Exp. 2, 4, and 5, the design was similar but had one fewer level of subplots, as there were no heat treatments (and source-sink manipulations were subplots within $\mathrm{N}$ regimes). In Exp. 6 and 7, main plots were the factorial combination of genotypes and $\mathrm{N}$ regimes, subplots were assigned to temperature regimes, and sub-subplots were assigned to source-sink manipulations. 
Publisher: AGRONOMY; Journal: CROPSCI:Crop Science; Copyright: Will notify... Volume: Will notify...; Issue: Will notify...; Manuscript: crop-2017-11-0676-ora; DOI: ; PII: $<$ txtPII $>$

TOC Head: ; Section Head: ; Article Type: ARTICLE

\section{Hybrids, Nitrogen Fertilization Regimes, and Heat Stress Treatments}

Hybrids grown were Lapopi (in Exp. 1-5, classified as short cycle FAO 450), Pioneer 31 N28 (PR31N28, in Exp. 1-6, classified as long cycle, FAO 700), and Pioneer 33Y72 (PR33Y72, in Exp. 7, also classified as long cycle, FAO 700). PR33Y72 replaced PR31N28 due to lack of seed availability, following manufacturer suggestions for correct replacement of the hybrid. In all cases, hybrids were selected considering farmers realistic options and for representing singlecross hybrids with different cycle duration but well adapted to the region (Table 1).

On these basic frameworks (experimental locations and seasons, and different hybrids in Exp. 1-5), we imposed a number of treatments. There were different $\mathrm{N}$ fertilization regimes in all experiments, and two heat stress conditions in Exp. 1, 3, 6, and 7 (Table 1). There were two $\mathrm{N}$ fertilization rates in Exp. 1 to 5 and three different rates combined with two application timings in Exp. 6 and 7 (Table 1). The aim of these treatments was to create a wide range of background growing conditions in which the responsiveness of grain weight to source-sink manipulations could be tested. Heat stress conditions were a control (unheated), a heat stress treatment imposed during the entire effective grain-filling period (Exp. 1 and 3), or a heat stress treatment imposed during the first $15 \mathrm{~d}$ of the effective grain-filling period (Exp. 6 and 7) (Table 1). To impose heat stress, we enclosed part of the plots with transparent polyethylene film (100- $\mu \mathrm{m}$ thickness) mounted on wood structures at the beginning of each heating period and removed it at the end (as illustrated in Ordóñez et al., 2015), leaving open the bottom $30 \mathrm{~cm}$ of all sides of each structure. This increased maximum daily air temperature in the enclosed canopies by $? 5^{\circ} \mathrm{C}$ (averaged across different heights of the canopy, see details in Ordóñez et al., 2015) while minimum temperature was unchanged. The great advantage of this treatment over studies under controlled conditions (in which most of research on high temperature has been done) is that treatments are imposed on plants in a real crop structure in the field. The main disadvantage of this treatment is that increasing temperature decreases vapor pressure deficit and incident radiation on the canopy. We realize that the reduced vapor pressure deficit is relevant in rainfed growing conditions but trust that it has negligible effects in our fully irrigated conditions. Reduction in incident radiation was, on average, $12 \%$ at noon of sunny days; throughout the day and across sunny and cloudy days, the reduction in incident radiation would be considerably less. In addition, as discussed in Ordóñez et al. (2015), the polyethylene film would have increased the proportion of diffuse radiation, which in turn increases radiation use efficiency for which a small reduction in incident radiation would have been compensated by this small increase in radiation use efficiency.

All in all, a range of 52 different background conditions were generated (experiments $\times$ hybrids $\times \mathrm{N}$ regimes $\times$ heat treatments), in each of which we imposed the source-sink manipulations.

\section{Source-Sink Manipulations}

In the present study, manipulation of source-sink relationships was restricted to the effective grain-filling period, imposing treatments $15 \mathrm{~d}$ after silking (in our growing conditions, always $>200^{\circ} \mathrm{C} \mathrm{d}$, with a base temperature of $8^{\circ} \mathrm{C}$ ). Timing was decided understanding that the period for grain number determination ends ? $15 \mathrm{~d}$ after silking (see references above), and that the lag phase in maize would hardly exceed $200^{\circ} \mathrm{C} d$ after silking (Maddonni et al., 1998). Therefore, by 
Publisher: AGRONOMY; Journal: CROPSCI:Crop Science; Copyright: Will notify... Volume: Will notify...; Issue: Will notify...; Manuscript: crop-2017-11-0676-ora; DOI: ; PII: $<$ txtPII $>$

TOC Head: ; Section Head: ; Article Type: ARTICLE

imposing the treatments $15 \mathrm{~d}$ after silking, no major confounding effects through altering grain size potential (as in Gambín et al., 2007) were expected. Thus, any responsiveness of grain size would be mostly related to the expected changes in assimilate availability per grain during grain filling.

To avoid any unexpected effect due to plant-to-plant phenotypic variations, very similar individual plants were selected at silking (same plant height and stem diameter, judged by naked eye, same leaf number, and same stage of development) and labeled within each particular background condition: in Exp. 1 to 5, six plants were labeled per experimental unit; in Exp. 6 and 7, 10 plants were labeled per experimental unit. All labeled plants were at the onset of silking when labeled, and the imposition of the source-sink treatments was $15 \mathrm{~d}$ after silking of each particular plant. Experimental units, in which source-sink manipulations were imposed, were the combination of experiment $\times$ hybrid $\times \mathrm{N}$ regime $\times$ heat stress condition. Within them, each source-sink manipulation (control, defoliated, and degrained) was performed on three different plants (and in experiments with degraining treatments, there was an additional plant used as a placebo, as explained below). As there were three blocks in each experiment, we had a total of nine plants for each source-sink manipulation treatment within each of the background conditions. In all cases (the 52 different background conditions across all experiments, Table 1), there was a control not being manipulated, as well as a potential source restriction through defoliations. In 12 of these background conditions (Exp. 6 and 7), a treatment for dramatically increasing the potential availability of assimilates for each growing grain during the effective period of grain growth was imposed through a novel degraining procedure.

Defoliations were made by removing leaf laminae from most leaf positions. Leaf removal was done by cutting leaves on the collar, between the lamina and the sheath. In Exp. 1 and 2, all leaf laminae were removed except the two leaves adjacent to the ear (those immediately below and above) that were left untouched. In Exp. 3 to 7, the third leaf below the ear, the leaf adjacent to the ear, the third leaf above the ear, and the flag leaf were left untouched and all the others were removed. Prior to defoliating each plant, the area of each individual leaf was computed (lamina length $\times$ maximum width $\times 0.75$; Rattalino Edreira and Otegui, 2012). Total leaf area per plant was calculated as the sum of all laminae. The intensity of defoliation in terms of leaf area removal was estimated based on the total leaf area and the leaf area of the remaining laminae after defoliation. Defoliation treatments represented $? 75$ and $65 \%$ reduction in total leaf area at the time of treatment imposition in Exp. 1 to 2 and 3 to 7, respectively.

Degraining was performed in Exp. 6 and 7 through a novel approach, eliminating alternate rows of grains of the ear (Fig. 1) $15 \mathrm{~d}$ after silking. The procedure started with carefully opening the husks, pulling them back from the tip to the base, and removing all silks. Then, the opened ear was disinfected by spraying $96 \%$ ethanol, and with a previously disinfected scalpel, all grains within a row of alternate rows were eliminated, roughly halving the number of grains of the treated ear. Immediately after, a broad-spectrum fungicide (chlorothalonil, $50 \%[\mathrm{w} / \mathrm{v}]$ suspension concentrate) was sprayed over the ear. Finally, husks were returned as close as possible to their original position and kept in place with elastic bands. From then on, once per week, each treated ear was opened and cleaned preventively with $96 \%$ ethanol to inhibit the development of any disease. 
Publisher: AGRONOMY; Journal: CROPSCI:Crop Science; Copyright: Will notify... Volume: Will notify...; Issue: Will notify...; Manuscript: crop-2017-11-0676-ora; DOI: ; PII: $<$ txtPII $>$

TOC Head: ; Section Head: ; Article Type: ARTICLE

In addition to the three plants manipulated in each of the 36 experimental units (12 background $\mathrm{N} \times$ temperature conditions and three replicates), in the 18 unheated experimental units, a sort of placebo was used to determine whether the manipulation to eliminate rows of grains might have affected grain growth in the remaining rows. In these plants (one per replicate, three per $\mathrm{N}$ regime treatment under unheated conditions), the placebo was produced applying exactly the same procedure but without using the scalpel (we peeled back the husks of the ear, sprayed them with $96 \%$ ethanol and then with the fungicide, closed the husks, and kept them together with an elastic band on the tip; then, once per week they were also opened and cleaned with $96 \%$ ethanol). We are aware of one single case in which a similar degraining procedure was made (Tollenaar and Daynard, 1978a), although in that case, not all grains were removed from the treated rows, the husks were completely excised, ears were then covered with brown paper bags, the plants were grown in pots under controlled conditions, and the effect of degraining on the weight of the remaining growing grains (in comparison with those from the same ear position in control plants) was not reported.

\section{Sampling, Determination, and Analyses}

At physiological maturity, all treated plants were sampled and taken to the laboratory. Once there, the ears of each plant were divided in three sections: the basal, central, and apical thirds of each ear. In each third, grains were separated from the cob, counted, oven dried for $72 \mathrm{~h}$ at $65^{\circ} \mathrm{C}$, and weighed. Finally, grains from different thirds were joined, milled, and used for $\mathrm{N}$ content determination by micro-Kjeldahl. Grains that for any reason aborted and could not continue growing after grain set (grains weighing $<20 \mathrm{mg}$ grain $^{-1}$ at maturity) were disregarded.

All data were subjected to ANOVA within each experiment to determine the significance of the effects of the different factors. However, the focus of this study was on the effects of sourcesink manipulations (Exp. 2, 4, and 5), as well as temperature and their interaction (Exp. 1, 3, 6, and 7). For this purpose, we analyzed the regression between the weight of the grains in the source or sink manipulated treatments against that in the unmanipulated controls and established whether the difference from the 1:1 line was statistically significant $(P<0.05)$ (i.e., when defoliation or degraining significantly modified grain weight).

To interpret the results we determined the response of grain weight to treatments and, as usually done in the literature (e.g., Borrás et al., 2004), we primarily presumed any significant response of grain weight to a treatment applied during grain filling as a sign of source limitation in the unmanipulated control. However, in our cases, we also analyzed whether there was any grain position hierarchy in the grain weight response. It was assumed that if a source limitation existed, there would be a competition among grains for limited assimilates and the competitive ability of the larger basal grains would be stronger (and consequently any penalty due to source limitation would be proportionally smaller) than that of the apical grains. Furthermore, if any reductions in grain weight due to defoliation were exclusively due to source limitation, the magnitude of the difference between control and defoliated plants would be noticeably larger under heat stress (which accelerates canopy senescence) than under unheated grain-filling conditions. 
Publisher: AGRONOMY; Journal: CROPSCI:Crop Science; Copyright: Will notify... Volume: Will notify...; Issue: Will notify...; Manuscript: crop-2017-11-0676-ora; DOI: ; PII: $<$ txtPII $>$

\section{TOC Head: ; Section Head: ; Article Type: ARTICLE}

\section{RESULTS}

The combination of experiments $\times$ hybrids $\times \mathrm{N}$ regimes $\times$ heat treatments produced 52 background conditions in which grain number ranged from ? 160 to $>700$ grains plant $^{-1}$, and the average grain weight ranged from ?150 to ?350 mg grain ${ }^{-1}$ (Fig. 2). Overall, there were rather significant effects of all treatments (including hybrids and $\mathrm{N}$ fertilization) on yield and its components, but in this particular study, we were only interested in, and focused the results on, whether grain filling was or was not source limited in any of the conditions analyzed. For the sake of simplicity, in this paper, results are focused on the effects of heat, source-sink treatments and their interaction on grain weight (for the effects of $\mathrm{N}$, hybrids, and heat on yield and its components, please see Ordóñez et al., 2015).

Heat stress imposed $15 \mathrm{~d}$ after silking reduced both grain number and average grain weight (Fig. 2, left panel). Although we imposed the high temperature treatment when it was expected not to affect grain number, grain number was slightly reduced (Fig. 2, left panel, inset). In addition, the defoliation treatments were imposed attempting not to affect grain number, but there was again a small effect in that ears of defoliated plants had slightly fewer grains than those of the unmanipulated control under both unheated and heated during the effective grain-filling period (Fig. 2, right panel). Naturally, degraining dramatically reduced the number of grains per plant (Fig. 2, right panel). Ranges within the unheated and heated treatments in grain filling, as well as within each of the source-sink treatments, were due to the different $\mathrm{N}$ fertilization regimes and to the different experiments. Within each of these thermal regimes, there was no relationship between grain number per plant and average grain weight (Fig. 2, left panel).

In all experiments in which heat and source-sink manipulations were applied, average grain weight was significantly affected, with the exception of Exp. 7, in which source-sink manipulations did not significantly affect grain weight (Table 2). It was also noticeable that, although interactions between heat and source-sink manipulations were significant in three out of the four experiments in which both treatments were combined, the magnitude of the interaction was negligible in comparison with that of the main factors (Table 2). The mean squares of the interactions were $<6 \%$ of the mean squares of the single factor with the strongest effect on average grain size.

\section{Responses to Defoliation}

Defoliation significantly reduced the average weight of the grains in six out of the seven experiments in which the treatment was imposed (Fig. 3). This reduction was, on average, $>50 \%$ in Exp. 1 and 2 and $>30 \%$ in Exp. 3, 5, and 6. In Exp. 4, over all cases, there was a significant reduction in grain weight but it was small (just over 20\%), and in one of the four cases, the reduction was not significant (unfertilized treatment of hybrid Lapopi). In Exp. 7, defoliation did not significantly reduce the final grain weight in any of the $\mathrm{N}$ treatments (Fig. 3, left panel).

Experiments 1, 3, 6, and 7 had defoliation and heat-stress treatments during grain filling. Expectedly, heat stress during grain filling reduced the weight of the grains as well, but the effect of defoliation was not larger in heated than in unheated plants (Fig. 3 middle panel), as would be expected if the reason for the decrease in grain weight due to heat stress was the reduction in assimilate availability associated with increased temperature. Furthermore, grain weight did not respond to defoliation in the unheated or heated plants of Exp. 7 (Fig. 3, left panel). Thus, 
Publisher: AGRONOMY; Journal: CROPSCI:Crop Science; Copyright: Will notify... Volume: Will notify...; Issue: Will notify...; Manuscript: crop-2017-11-0676-ora; DOI: ; PII: $<$ txtPII $>$

TOC Head: ; Section Head: ; Article Type: ARTICLE

temperature did reduce grain weight, but it did not make the grains more sensitive to defoliation (Fig. 3, middle panel).

Pooling data together, a single relationship for all cases was evident, excluding Exp. 7, between grain weights in defoliated and control plants (Fig. 3, left panel). As the slope was clearly $<1$, a higher sensitivity to defoliation was evident when conditions (given by different experiments and different $\mathrm{N}$ fertilization regimes within experiments) led to larger rather than to smaller grains (Fig. 3, left panel). This general argument does not hold when the condition reducing grain weight is the exposure to heat stress during grain filling. Thus, even when in the control these grains were clearly smaller than in the unheated plants, the reduction imposed by defoliation was similar (Fig. 3, middle panel). Residuals corresponding to unheated plants were positive, and those corresponding to heat-stressed plants were negative (Fig. 3, right panel). This does not mean that defoliation produced stronger penalties in heat-stressed plants; it simply reflects that the reduction in grain size produced by heat stress (for each particular condition, grains heated were always lighter than the grains in the unheated controls) did not change the sensitivity to defoliation.

When analyzing the response of different grain positions along the ear (those of the base, the middle, or the tip of the ear, which constitutively differ in size), we found no clear differences in their responsiveness to defoliation (Fig. 4). Defoliation did not consistently penalize the growth of the grains in the apical third of the ear (Fig. 4), as it would be expected that a reduction in assimilate availability would have more strongly affected the weakest grains. There was one exception out of 11 cases, however, in which apical grains responded to the defoliation treatment significantly more than basal and central grains (unheated condition of Exp. 7, Fig. 4), but this response was not evident in the heated treatment of the same experiment. We also found an opposite exceptional case under heated conditions of Exp. 3, in which the weight of apical grains was not significantly reduced by defoliation, whereas that of grains from the other positions was significantly reduced (Fig. 4). There was also one example in which apical grains responded quantitatively more than basal and central grains (Exp. 2), but in all other cases, apical, central, and basal grains responded to defoliation virtually identically. All in all, there were no clear differences in responsiveness of the grains of the different thirds of the ear, disregarding their different hierarchies when considering the weight loss produced by defoliation (Fig. 4, bottom right panel). Naturally, as the weight of the apical grains are constitutively smaller than those of the basal grains (see figures on top of bars in Fig. 4, bottom right panel), the same reduction in weight resulted in different reductions in relative terms (i.e., virtually the same weight loss due to defoliation of ? $100 \mathrm{mg} \mathrm{grain}^{-1}$, represented a reduction of ?32, 34, and $54 \%$ in basal, central, and apical grains, respectively).

The magnitude of the reduction in grain weight due to defoliation was similar under unheated controls and heat stress during grain filling (Fig. 4). This similarity was consistent across grain positions: heat stress did not consistently increase the damage in the apical grains with respect to the damage produced in basal and central grains (Fig. 4). The fact that the response of grain weight to heat was not hierarchical (i.e., grains of different size responded similarly) supports the idea that heat stress does affect grain weight directly, but rather through increasing competition among grains due to restricted availability of assimilates as a consequence of accelerating leaf senescence. 
Publisher: AGRONOMY; Journal: CROPSCI:Crop Science; Copyright: Will notify... Volume: Will notify...; Issue: Will notify...; Manuscript: crop-2017-11-0676-ora; DOI: ; PII: $<$ txtPII $>$

TOC Head: ; Section Head: ; Article Type: ARTICLE

Defoliation treatments tended to increase grain $\mathrm{N}$ concentration, although the increase was relatively moderate (Fig. 5, right panel), likely because the same treatment that reduced grain weight also reduced the source of $\mathrm{N}$ for grain filling. Although the increase in protein concentration due to heat stress was proportional to the decrease produced in grain size, the reduction in grain weight produced by defoliation caused a marginal increase in protein concentration (Fig. 5). In fact, the grains of the plants defoliated but unheated were, on average, smaller than those from plants not defoliated but exposed to heat stress during grain filling, but their grain protein concentration was also lower (Fig. 5).

\section{Responses to Degraining}

The degraining we imposed was a novel approach to determine to what degree grains compete for limited resources during grain filling. The first issue considered was whether the degraining treatment applied was reasonably valid to analyze responsiveness of grain size to a potential reduction in competition for resources during grain filling. For this approach to be valid, (i) it should have affected grains per ear in a magnitude commensurate with the expected outcome of the treatment, and (ii) the manipulation made to impose the treatment should not have affected the growth of the remaining grains. The former condition was satisfied, as the degraining treatment effectively reduced the number of grains within the expected range (Fig. 6, left panel). Grain number in the degrained plants was on average slightly less than half the number of grains in the control plants, under either heat stress condition (Fig. 6, left panel). Grain number ranged from ?300 to ?600 grains plant ${ }^{-1}$ in unheated conditions, and from ?250 to ?550 grains plant $^{-1}$ in plants exposed to heat stress $15 \mathrm{~d}$ after silking. In degrained plants, these ranges were ?125 to 300 and 100 to 300 grains plant $^{-1}$, respectively. The manipulation required for degraining produced no consistent effects on the final size of the grains (Fig. 6, right panel). There was larger variation around the 1:1 ratio for the weight of the grains in the placebos than in the unmanipulated controls. This was expected, as even when the plants selected for applying the treatments (including the placebo) were selected to have identical appearance, they could not be expected to possess strictly identical grain weights. As the number of plants was limited for the placebos, the error in their average was larger than in the unmanipulated controls, for which we had threefold more plants treated. All in all, it seems clear that the manipulation required to impose the degraining treatment did not produce any significant impairment on the capacity of the grains to grow similarly to those of the unmanipulated control plants.

Degraining did not increase grain weight in any of the experiments under unheated or heatstressed conditions (Fig. 7, top panels). Although there seemed be a trend for the grain weight of the heat-stressed plants to be more responsive, differences were not significant. Grain weight in the degrained plants was not increased at all under unheated conditions, and the increase in the heat-stressed plants was not significant (and negligible compared with the reduction in grain number).

There was no clear and consistent increase in grain weight as a response to degraining treatment for the whole population of grains in each condition, or for grains of particular ear positions (Fig. 7, bottom panels). Removing neighbor grains did not increase the weight of the remaining ones at any position (Fig. 7, bottom panels), implying that grains from the apical third of the ear are smaller due to constitutive reasons (i.e., they are inherently smaller). Therefore, the 
Publisher: AGRONOMY; Journal: CROPSCI:Crop Science; Copyright: Will notify... Volume: Will notify...; Issue: Will notify...; Manuscript: crop-2017-11-0676-ora; DOI: ; PII: $<$ txtPII $>$

TOC Head: ; Section Head: ; Article Type: ARTICLE

idea that grains might compete for limited photoassimilates during the effective grain-filling period was not supported in the present study (Fig. 7).

Heat stress reduced grain weight at all positions along the ear in each experiment. There was no consistent evidence that removing competing grains would reverse, at least in part, the penalty in grain weight produced by heat stress (Fig. 7). This result strengthens the awareness that heat directly reduces the capacity of the grains to grow, and even though it accelerates senescence as well, there was no indirect effect of heat on grain size through limiting the availability of assimilates.

Degraining did consistently increase grain $\mathrm{N}$ concentration under both unheated and heatstressed conditions (Fig. 8).

\section{DISCUSSION}

The observed grain weight response to defoliations in our study, across a large range of field conditions, agrees with conclusions from the meta-analysis conducted by Borrás et al. (2004) and studies published since then. Grain weight was generally reduced when the availability of assimilates per growing grain through defoliating the plants $15 \mathrm{~d}$ after silking was potentially diminished. There was a broad, and not a full, agreement because in one of the seven experiments we performed, as well as one of the four cases analyzed in Exp. 4, there was no reduction in grain size when plants were defoliated. Therefore, considering average grain weight changes, our results would largely support that maize grain growth would apparently be source limited if a shortage of assimilates is imposed during grain filling. This apparent source limitation for grain growth in maize is (i) different from what it is expected in other cereals (like wheat or barley), and (ii) against the general concept that grain weight possess very low plasticity. Studies modifying source-sink balances during grain filling have been very common in wheat and barley, and in the vast majority of the cases reductions in grain weight in response to shadings or defoliations are hardly noticed (Slafer and Savin, 1994; Borrás et al., 2004; Serrago et al., 2013), unless rather radical treatments were imposed (e.g., shading $>80 \%$ of the incoming radiation during the whole grain-filling period; Sandaña et al., 2009; Serrago et al., 2013). However, the maize response seems rather proportional to any source reduction level (Borrás et al., 2004). From an evolutionary perspective, plants would have much less plasticity in grain weight than in grain number (Sadras, 2007; Sadras and Slafer, 2012). Therefore, grain weight would not be expected to respond proportionally to changes in actual photosynthesis during grain filling, and the low plasticity would not be compatible with grain filling being largely source limited. In other words, a basic principle for a low plasticity of grain size is that the capacity of the canopy to offer assimilates would be in excess with respect to the demand of growing grains. Consequently, most grain crops would hardly be source limited during the effective grain-filling period, whereas in virtually all grain crops, yield would be strongly source limited during the critical period for grain number determination (Slafer and Savin, 2006).

To build up on a more robust interpretation of whether reductions in maize grain weight in response to defoliations represent that grain growth is source limited, the present study (i) innovatively combined defoliations with heat stress during grain filling in several experiments, and (ii) determined not only the average weight of all grains but also the weight of the grains from different positions of the ear (possessing different potential sizes) in all experiments. Both 
Publisher: AGRONOMY; Journal: CROPSCI:Crop Science; Copyright: Will notify... Volume: Will notify...; Issue: Will notify...; Manuscript: crop-2017-11-0676-ora; DOI: ; PII: $<$ txtPII $>$

TOC Head: ; Section Head: ; Article Type: ARTICLE

approaches offer a new and resourceful methodology to interpret whether source limitation may be the cause of reduced grain weight in defoliated plants. In the three experiments combining heat and defoliation in which grain weight was significantly and markedly reduced by defoliation in the unheated condition, there was a similar reduction when plants were subjected to heat stress. Both approaches produced new evidence that conflicts with the interpretation that grain weight was less in defoliated plants due to source-limited grain filling. Heat stress accelerates leaf senescence (Badu Apraku et al., 1983; Slafer and Miralles, 1992; De la Haba et al., 2014), and therefore if grain filling would have been taking place under source limitation, defoliation in heated plants would have reduced grain weight much more than in unheated controls, something that was not the case in any of the experiments. Second, if reduction in grain weight in response to defoliation was the consequence of grain growth being source limited, there should have been established competition among grains for limited resources to be filled. If defoliation produced severe competition for limited assimilates, the response must have been hierarchical: strong competitors must lose fewer resources than weak competitors in absolute terms as well. It would be tricky to accept that basal grains would be equally restricted in access to assimilate as apical grains. Therefore, a hierarchical magnitude of the penalty in grain weight from the base to the tip of the ear would have been expected. This hierarchical response has been empirically determined since early work by Daynard and Duncan (1969) studying what determines the maturity of maize grains. They stated that if stress occurs during the effective grain-filling period, the grains of the tip of the ear would be those most affected, whereas grains from the base would fill as in the nonstressed condition (Daynard and Duncan, 1969), and therefore the hierarchy would be clear in absolute amounts as well. We are not aware of other studies with defoliations that analyzed the response of different grain populations, but in the present study, this expected hierarchy did not occur. Defoliation reduced the final weight of the grains similarly, disregarding whether they were of the basal, central, or apical parts of the ears. Definitively, abortion of grains is clearly related to source availability (normally grain number is a function of plant growth rate during the critical period; e.g., Vega et al., 2001), and when plants are stressed in the critical period for grain number determination, the reduction in number of grains is higher in the tip than in the base of the ears (and this reduction is clearly seen in absolute terms, not just as a percentage of grains in the unstressed controls), because apical florets represent weaker sinks than basal florets fertilized earlier (Daynard and Duncan, 1969). Then, the reduction in grain size produced by defoliation may be related to other reasons than increased competition for limited assimilates in defoliated plants, and the interpretation of reduced grain weight under reduced source-sink balance would not be that grains were source limited. There may be signals associated with the treatments, as signals may affect organs similarly, independently of the hierarchies (as temperature does, see below). We are aware of another study in which reduction in source per growing grain was analyzed independently for grains in the base and tip of the ears, although the treatment was not defoliation but shading $45 \%$ of the incoming radiation imposed from $2 \mathrm{wk}$ after silking to maturity (Andrade and Ferreiro, 1996). If the grains in the control plants of that study were growing close to a source-limited condition, the reduction due to increased competition for limited resources in the shaded plants should have been (i) on average $? 45 \%$ (the intensity of shading), and (ii) more dramatic in grains of the tip than in those of the base of the ears, as the latter would be stronger competitors for limited resources. Although reductions in grain weight due to shading were always statistically significant (Andrade and Ferreiro, 1996), neither of the two premises to conclude that grains in the control plants were growing close to 
Publisher: AGRONOMY; Journal: CROPSCI:Crop Science; Copyright: Will notify... Volume: Will notify...; Issue: Will notify...; Manuscript: crop-2017-11-0676-ora; DOI: ; PII: $<$ txtPII $>$

TOC Head: ; Section Head: ; Article Type: ARTICLE

source limitation were fulfilled. First, the magnitude of the reduction was only marginal (?11\%) in the first growing season (in the second one, the reduction was more relevant, yet less than expected). Second, and in agreement with our results, the magnitude of the penalty was similar (or even less) for the weaker grains of the apical part of the ear and the dominant grains of the basal part of the ear (see Fig. 2 in Andrade and Ferreiro, 1996), suggesting again that the reduction would hardly be due to increased competition due to shading, as the response was not hierarchical. Stem reserves are recognized as a relevant source of assimilates to fill the grains when stressful conditions impair actual photosynthesis during grain filling (Blum et al., 1997). The fact that stem reserves are reduced in response to treatments diminishing actual photosynthesis during grain filling (Jones and Simmons, 1983; Kiniry et al., 1992) can explain why grain growth may still be sink limited in defoliated plants.

Although we cannot offer a solid alternative hypothesis for the commonly found reduction in grain growth due to defoliations (or shading) during the effective grain-filling period, it seems hardly possible to straightforwardly accept that it reflects a source limitation. Something else, beyond an increased competition, could be behind the grain size reduction in plants defoliated or shaded during the effective grain-filling period, and it would be more than worthwhile to count with further and more detailed studies aiming to determine the causes of such reductions.

A complementary support of the overall conclusion that grain growth is not limited by the source during the effective grain-filling period would be provided by having grain weights largely unresponsive to increases in the source-sink ratio during grain filling. In maize, different treatments have been applied to increase the source-sink ratio relative to a control, but the approaches used were always difficult to be interpreted. The most common approaches included modifying the crop structure (plant density), controlled pollination to reduce the number of grains set per unit of biomass around silking, and thinning plants a few weeks after silking. Both changes in plant density and controlled pollination (bagging ears at silking) may also affect grain weight potential, and then differences in grain size at maturity may better reflect these effects on grain size potential than the degree of source or sink limitation during the effective grain-filling period. Thinning plants after the lag phase is, in principle, a much cleaner treatment, as it affects the potential capacity of plant growth after grain number and the potential size of the grains have been established. However, the problem is that depending on the canopy structure of the control, a particular thinning treatment may affect more or less the potential increase in source per growing grain, and then results may be inconclusive. The approach designed in the present study offers for the first time in maize, as far as we are aware, a direct and quantitatively certain increase in source-sink balance during the effective grain-filling period. The other two unique cases in which a treatment directly removing grains was imposed before the present study (Jones and Simmons, 1983; Kiniry et al., 1990) did not yield conclusive evidence. This is because in these two earlier studies, the treatments were imposed by cutting half of the ear and covering the amputated surface with petroleum jelly. Although it was an interesting attempt to directly reduce sink strength, it had the problem that the responses could only be seen in basal grains, and if there was any source limitation for grain growth, the apical grains would be those most strongly responsive (see above). Furthermore, in some cases, there were unexpected reductions in grain weight in response to a treatment imposed to remove competition (Kiniry et al., 1990), evidencing that the imposition of the treatment would have produced negative collateral effects on grain growth. The degraining treatment we imposed is novel, as it (i) did not alter the 
Publisher: AGRONOMY; Journal: CROPSCI:Crop Science; Copyright: Will notify... Volume: Will notify...; Issue: Will notify...; Manuscript: crop-2017-11-0676-ora; DOI: ; PII: $<$ txtPII $>$

TOC Head: ; Section Head: ; Article Type: ARTICLE

distribution of grains of different hierarchies in the ear, and (ii) had placebos, evidencing that there were no noticeable negative collateral effects of the treatments on the growth of the remaining grains (which considerably extends previous evidence that removing the husks did not affect grain weight; Tollenaar and Daynard, 1978a). Thus, although in some previous studies maize grain weight significantly increased in response to increases in assimilate availability per grain (Borrás et al., 2003; Kiniry et al., 1990) and lack of source strength to fill the grains was suggested to be the cause of grain weight reductions with late sowings (Cirilo and Andrade, 1996), our results from the novel degraining treatment corroborate the most common scenario in maize: grain weight is mostly unresponsive to increases in source strength per grain during grain filling (Borrás et al., 2004). Nevertheless, this should not be seen as mere additional evidence of something done in the past. The present study offers the first evidence of direct reduction in grain number during grain filling with an approach not having collateral effects, and respecting the distribution of grains of different potential sizes in field conditions. Thus, it provides strong support of what has been said a number of times from more indirect approaches. The strength comes not only from the fact that the treatment imposition had no collateral effect, but also from the fact that the lack of response was evident for the different grains, representing different potential sizes, and was not altered in heated conditions.

Heat affected grain size by directly affecting the capacity of the grains to grow. This conclusion was reached in our previous study (Ordóñez et al., 2015) due to the fact that heat stress reduced grain size even when it increased source-sink ratio (by inducing late abortion of few grains while not affecting much post-flowering growth). In the present study, the direct effect can be seen straightforwardly because (i) the penalty imposed by the heat stress was neither consistently worsened by defoliation nor systematically diminished by degraining during the effective grain-filling period, and (ii) the penalty was similar for grains of different potential size (apical, central, and basal parts of the ear). Thus, the present study further strengthens the conclusion that the effect of heat stress during the period of grain filling is mainly direct (as also concluded by Rattalino Edreira et al., 2014; and in line with earlier wheat studies: Jenner et al., 1991; Slafer and Miralles, 1992).

\section{CONCLUSIONS}

We presented a novel degraining approach for increasing maize assimilate availability per grain during grain filling, allowing analysis of the results on grains from different positions of the ear, including apical grains. Grain weight was largely unresponsive to increases in availability of assimilates during the effective grain-filling period (when the potential size of the grains has already been established) but was strongly diminished by reducing the availability of assimilates in $>85 \%$ of the cases analyzed. Therefore, it might be straightforwardly concluded that our results support the statement that maize grains would be growing in "a delicate balance between sink and source" (Tollenaar and Daynard, 1982). However, this commonly accepted situation (Borrás et al., 2004) might need to be rethought in light of the more detailed analyses offered in our study. It seems unlikely that the reductions in grain size in response to defoliation could be ascribed merely and simply to increased competition produced by the defoliation: the response was not hierarchical (as expected if the reason for the response was competition), and it was not affected by heat stress. Heat stress affected grain growth capacity directly and not through reducing the availability of assimilates expected from the acceleration of senescence. First, 
Publisher: AGRONOMY; Journal: CROPSCI:Crop Science; Copyright: Will notify... Volume: Will notify...; Issue: Will notify...; Manuscript: crop-2017-11-0676-ora; DOI: ; PII: $<$ txtPII $>$

TOC Head: ; Section Head: ; Article Type: ARTICLE

neither defoliation increased nor degraining diminished the penalty imposed by heat. Second, the penalty imposed by heat on grain size was similar for grains of different potential grain size.

\section{Conflict of Interest}

The authors declare that there is no conflict of interest.

\section{ACKNOWLEDGMENTS}

We gratefully acknowledge technicians of the Crop Physiology Laboratory for help in the management of the experiments, particularly with the tedious degraining required at relatively large scale in field plots. We thank Lucas Borrás (University of Rosario, Argentina) and Sotirios Archontoulis (Iowa State University, IA) for their comments and suggestions in earlier versions of this paper, as well as María Othgui (Associate Editor of Crop Science) for valuable suggestions made directly on the PDF file of the original submission. Funding was provided by Project 8031 of the Regional Fund for Agricultural Technology (FONTAGRO). R.A. Ordóñez held a University of Lleida predoctoral scholarship.

\section{REFERENCES}

Ahmadi, M., W.J. Wiebold, and J.E. Beuerlein. 1993. Grain yield and mineral composition of corn as influenced by endosperm type and nitrogen. Commun. Soil Sci. Plant Anal. 24:2409-2426. doi:10.1080/00103629309368964

Aluko, G.K., and K.S. Fischer. 1988. The effect of changes of assimilate supply around flowering on grain sink size and yield of maize (Zea mays L.) cultivars of tropical and temperate adaptation. Aust. J. Agric. Res. 39:153161. doi:10.1071/AR9880153

Andrade, F.H., and M.A. Ferreiro. 1996. Reproductive growth of maize, sunflower and soybean at different source levels during grain filling. Field Crops Res. 48:155-165. doi:10.1016/S0378-4290(96)01017-9

Andrade, F.H., C. Vega, S. Uhart, A. Cirilo, M. Cantarero, and O. Valentinuz. 1999. Kernel number determination in maize. Crop Sci. 39:453-459. doi:10.2135/cropsci1999.0011183X0039000200026x

Badu-Apraku, B., R.B. Hunter, and M. Tollenaar. 1983. Effect of temperature during grain filling on whole plant and grain yield in maize (Zea mays L.). Can. J. Plant Sci. 63:357-363. doi:10.4141/cjps83-040

Bingham, I.J., J. Blake, M.J. Foulkes, and J. Spink. 2007. Is barley yield in the UK sink limited? Field Crops Res. 101:212-220. doi:10.1016/j.fcr.2006.11.004

Blum, A., G. Golan, J. Mayer, and B. Sinmena. 1997. The effect of dwarfing genes on sorghum grain-filling from remobilized stem reserves, under stress. Field Crops Res. 52:43-54. doi:10.1016/S0378-4290(96)03462-4

Borrás, L., and B.L. Gambín. 2010. Trait dissection of maize kernel weight: Towards integrating hierarchical scales using a plant growth approach. Field Crops Res. 118:1-12. doi:10.1016/j.fcr.2010.04.010

Borrás, L., G.A. Slafer, and M.E. Otegui. 2004. Seed dry weight response to source-sink manipulations in wheat, maize and soybean: A quantitative reappraisal. Field Crops Res. 86:131-146. doi:10.1016/j.fcr.2003.08.002

Borrás, L., and M.E. Westgate. 2006. Predicting maize kernel sink capacity early in development. Field Crops Res. 95:223-233. doi:10.1016/j.fcr.2005.03.001

Borrás, L., M.E. Westgate, and M.E. Otegui. 2003. Control of kernel weight and kernel water relations by postflowering source-sink ratio in maize. Ann. Bot. (Lond.) 91:857-867. doi:10.1093/aob/mcg090

Brocklehurst, P.A. 1977. Factors controlling grain weight in wheat. Nature 266:348-349. doi:10.1038/266348a0

Cairns, J.E., J. Crossa, P.H. Zaidi, P. Grudloyma, C. Sanchez, J.L. Araus, et al. 2013. Identification of drought, heat, and combined drought and heat tolerant donors in maize. Crop Sci. 53:1335-1346. doi:10.2135/cropsci2012.09.0545

Calderini, D.F., L.G. Abeledo, R. Savin, and G.A. Slafer. 1999a. Effect of temperature and carpel size during preanthesis on potential grain weight in wheat. J. Agric. Sci. 132:453-459. doi:10.1017/S0021859699006504 
Publisher: AGRONOMY; Journal: CROPSCI:Crop Science; Copyright: Will notify... Volume: Will notify...; Issue: Will notify...; Manuscript: crop-2017-11-0676-ora; DOI: ; PII: $<$ txtPII $>$

\section{TOC Head: ; Section Head: ; Article Type: ARTICLE}

Calderini, D.F., L.G. Abeledo, R. Savin, and G.A. Slafer. 1999b. Final grain weight in wheat as affected by short periods of high temperature during pre-and postanthesis under field conditions. Aust. J. Plant Physiol. 26:453458. doi:10.1071/PP99015

Calderini, D.F., and M.P. Reynolds. 2000. Changes in grain weight as a consequence of de-graining treatments at pre- and post-anthesis in synthetic hexaploid lines of wheat (Triticum durum $\times$ T. tauschii). Funct. Plant Biol. 27:183-191. doi:10.1071/PP99066

Calderini, D.F., M.P. Reynolds, and G.A. Slafer. 2006. Source-sink effects on grain weight of bread wheat, durum wheat, and triticale at different locations. Aust. J. Agric. Res. 57:227-233. doi:10.1071/AR05107

Cárcova, J., B. Andrieu, and M.E. Otegui. 2003. Silk elongation in maize: Relationship with flower development and pollination. Crop Sci. 43:914-920. doi:10.2135/cropsci2003.9140

Cartelle, J., A. Pedró, R. Savin, and G.A. Slafer. 2006. Grain weight responses to postanthesis spikelet-trimming in an old and a modern wheat under Mediterranean conditions. Eur. J. Agron. 25:365-371. doi:10.1016/j.eja.2006.07.004

Cerrudo, A., J. Di Matteo, E. Fernandez, M. Robles, L.O. Pico, and F.H. Andrade. 2013. Yield components of maize as affected by short shading periods and thinning. Crop Pasture Sci. 64:580-587. doi:10.1071/CP13201

Chapman, S.C., and G.O. Edmeades. 1999. Selection improves drought tolerance in tropical maize populations: II. Direct and correlated responses among secondary traits. Crop Sci. 39:1315-1324. doi:10.2135/cropsci1999.3951315x

Chen, Y., G. Hoogenboom, Y. Ma, B. Li, and Y. Guo. 2013. Maize kernel growth at different floret positions of the ear. Field Crops Res. 149:177-186. doi:10.1016/j.fcr.2013.04.028

Cirilo, A.G., and F.H. Andrade. 1996. Sowing date and kernel weight in maize. Crop Sci. 36:325-331. doi:10.2135/cropsci1996.0011183X003600020019x

Daynard, T.B., and W.G. Duncan. 1969. The black layer and grain maturity in corn. Crop Sci. 9:473-476. doi:10.2135/cropsci1969.0011183X000900040026x

De la Haba, P., L. De la Mata, E. Molina, and E. Agüera. 2014. High temperature promotes early senescence in primary leaves of sunflower (Helianthus annuus L.) plants. Can. J. Plant Sci. 94:659-669. doi:10.4141/cjps2013-276

Dreccer, M.F., C. Grashoff, and R. Rabbinge. 1997. Source-sink ratio in barley (Hordeum vulgare L.) during grain filling: Effects on senescence and grain protein concentration. Field Crops Res. 49:269-277. doi:10.1016/S0378-4290(96)01002-7

Echarte, L., F.H. Andrade, V.O. Sadras, and P. Abbate. 2006. Kernel weight and its response to source manipulations during grain filling in Argentinean maize hybrids released in different decades. Field Crops Res. 96:307-312. doi:10.1016/j.fcr.2005.07.013

Edmeades, G.O., and T.B. Daynard. 1979. The relationship between final yield and photosynthesis at flowering in individual maize plant. Can. J. Plant Sci. 59:585-601. doi:10.4141/cjps79-097

Ferrante, A., R. Savin, and G.A. Slafer. 2012. Differences in yield physiology between modern, well adapted durum wheat cultivars grown under contrasting conditions. Field Crops Res. 136:52-64. doi:10.1016/j.fcr.2012.07.015

Ferrise, R., A. Triossi, P. Stratonovitch, M. Bindi, and P. Martre. 2010. Sowing date and nitrogen fertilisation effects on dry matter and nitrogen dynamics for durum wheat: An experimental and simulation study. Field Crops Res. 117:245-257. doi:10.1016/j.fcr.2010.03.010

Frey, N.M. 1981. Dry matter accumulation in kernels of maize. Crop Sci. 21:118-122. doi:10.2135/cropsci1981.0011183X002100010032x

Gambín, B.L., L. Borrás, and M.E. Otegui. 2006. Source-sink relations and kernel weight differences in maize temperate hybrids. Field Crops Res. 95:316-326. doi:10.1016/j.fcr.2005.04.002 
Publisher: AGRONOMY; Journal: CROPSCI:Crop Science; Copyright: Will notify... Volume: Will notify...; Issue: Will notify...; Manuscript: crop-2017-11-0676-ora; DOI: ; PII: $<$ txtPII $>$

\section{TOC Head: ; Section Head: ; Article Type: ARTICLE}

Gambín, B.L., L. Borrás, and M.E. Otegui. 2007. Is maize kernel size limited by its capacity to expand? Maydica $52: 431-441$.

Gambín, B.L., L. Borrás, and M.E. Otegui. 2008. Kernel weight dependence upon plant growth at different grainfilling stages in maize and sorghum. Aust. J. Agric. Res. 59:280-290. doi:10.1071/AR07275

Hanft, J.M., R.J. Jones, and A.B. Stumme. 1986. Dry matter accumulation and carbohydrate concentration patterns of field-grown and in vitro cultured maize kernels from the tip and middle ear positions. Crop Sci. 26:568-572. doi:10.2135/cropsci1986.0011183X002600030029x

Hasan, A.K., J. Herrera, C. Lizana, and D.F. Calderini. 2011. Carpel weight, grain length and stabilized grain water content are physiological drivers of grain weight determination of wheat. Field Crops Res. 123:241-247. doi:10.1016/j.fcr.2011.05.019

Jenner, C.F., T.D. Ugalde, and D. Aspinall. 1991. The physiology of starch and protein deposition in the endosperm of wheat. Aust. J. Plant Physiol. 18:211-226. doi:10.1071/PP9910211

Jones, R.J., and S.R. Simmons. 1983. Effect of altered source-sink ratio on growth of maize kernels. Crop Sci. 23:129-134. doi:10.2135/cropsci1983.0011183X002300010038x

Kiniry, J.R., and J.T. Ritchie. 1985. Shade-sensitive interval of kernel number of maize. Agron. J. 77:711-715. doi:10.2134/agronj1985.00021962007700050012x

Kiniry, J.R., C.R. Tischler, W.D. Rosenthal, and T.J. Gerik. 1992. Nonstructural carbohydrate utilization by sorghum and maize shaded during grain growth. Crop Sci. 32:131-137. doi:10.2135/cropsci1992.0011183X003200010029x

Kiniry, J.R., C.A. Wood, D.A. Spanel, and A.J. Bockholt. 1990. Seed weight response to decreased seed number in maize. Agron. J. 82:98-102. doi:10.2134/agronj1990.00021962008200010023x

Kirby, E.J.M. 1988. Analysis of leaf, stem and ear growth in wheat from terminal spikelet stage to anthesis. Field Crops Res. 18:127-140. doi:10.1016/0378-4290(88)90004-4

Lobell, D.B., M. Bänziger, C. Magorokosho, and B. Vivek. 2011. Nonlinear heat effects on African maize as evidenced by historical yield trials. Nat. Clim. Chang. 1:42-45. doi:10.1038/nclimate1043

Maddonni, G.A., M.E. Otegui, and R. Bonhomme. 1998. Grain yield components in maize II. Postsilking growth and kernel weight. Field Crops Res. 56:257-264. doi:10.1016/S0378-4290(97)00094-4

Ordóñez, R.A., R. Savin, C.M. Cossani, and G.A. Slafer. 2015. Yield response to heat stress as affected by nitrogen availability in maize. Field Crops Res. 183:184-203. doi:10.1016/j.fcr.2015.07.010

Otegui, M.E. 1995. Prolificacy and grain yield components in modern Argentinian maize hybrids. Maydica 40:371376.

Otegui, M.E. 1997. Kernel set and flower synchrony within the ear of maize: II. Plant population effects. Crop Sci. 37:448-455. doi:10.2135/cropsci1997.0011183X003700020024x

Otegui, M.E., F.H. Andrade, and E.E. Suero. 1995. Growth, water use, and kernel abortion of maize subjected to drought at silking. Field Crops Res. 40:87-94. doi:10.1016/0378-4290(94)00093-R

Otegui, M.E., and R. Bonhomme. 1998. Grain yield components in maize I. Ear growth and kernel set. Field Crops Res. 56:247-256. doi:10.1016/S0378-4290(97)00093-2

Pedró, A., R. Savin, D.Z. Habash, and G.A. Slafer. 2011. Physiological attributes associated with yield and stability in selected lines of a durum wheat population. Euphytica 180:195-208. doi:10.1007/s10681-011-0352-y

Rattalino Edreira, J.I., L.I. Mayer, and M.E. Otegui. 2014. Heat stress in temperate and tropical maize hybrids: Kernel growth, water relations and assimilate availability for grain filling. Field Crops Res. 166:162-172. doi:10.1016/j.fcr.2014.06.018

Rattalino Edreira, J.I., and M.E. Otegui. 2012. Heat stress in temperate and tropical maize hybrids: Differences in crop growth, biomass partitioning and reserves use. Field Crops Res. 130:87-98. doi:10.1016/j.fcr.2012.02.009 
Publisher: AGRONOMY; Journal: CROPSCI:Crop Science; Copyright: Will notify... Volume: Will notify...; Issue: Will notify...; Manuscript: crop-2017-11-0676-ora; DOI: ; PII: $<$ txtPII $>$

\section{TOC Head: ; Section Head: ; Article Type: ARTICLE}

Reddy, V.M., and B.T. Dynard. 1983. Endosperm characteristics associated with rate of grain filling and kernel size in corn. Maydica 28:239-355.

Richards, R.A. 1996. Increasing yield potential in wheat- source and sink limitations. In: M.P. Reynolds, et al., editors, Increasing yield potential in wheat: Breaking the barriers. CIMMYT, Mexico City. p. 134-149.

Sadras, V.O. 2007. Evolutionary aspects of the trade-off between seed size and number in crops. Field Crops Res. 100:125-138. doi:10.1016/j.fcr.2006.07.004

Sadras, V.O., and G.A. Slafer. 2012. Environmental modulation of yield components in cereals: Heritabilities reveal a hierarchy of phenotypic plasticities. Field Crops Res. 127:215-224. doi:10.1016/j.fcr.2011.11.014

Sala, R.G., M.E. Westgate, and F.H. Andrade. 2007. Source/sink ratio and the relationship between maximum water content, maximum volume, and final dry weight of maize kernels. Field Crops Res. 101:19-25. doi:10.1016/j.fcr.2006.09.004

Sandaña, P.A., C.I. Harcha, and D.F. Calderini. 2009. Sensitivity of yield and grain nitrogen concentration of wheat, lupin and pea to source reduction during grain filling. A comparative survey under high yielding conditions. Field Crops Res. 114:233-243. doi:10.1016/j.fcr.2009.08.003

Serrago, R.A., I. Alzueta, R. Savin, and G.A. Slafer. 2013. Understanding grain yield responses to source-sink ratios during grain filling in wheat and barley under contrasting environments. Field Crops Res. 150:42-51. doi:10.1016/j.fcr.2013.05.016

Severini, A.D., L. Borrás, M.E. Westgate, and A.G. Cirilo. 2011. Kernel number and kernel weight determination in dent and popcorn maize. Field Crops Res. 120:360-369. doi:10.1016/j.fcr.2010.11.013

Slafer, G.A. 2003. Genetic basis of yield as viewed from a crop physiologist's perspective. Ann. Appl. Biol. 142:117-128. doi:10.1111/j.1744-7348.2003.tb00237.x

Slafer, G.A., F.G. González, A.G. Kantolic, E.M. Whitechurch, L.G. Abeledo, D.J. Miralles, and R. Savin. 2006. Grain number determination in major grain crops. In: A.S. Basra, editor, Handbook of seed and science and technology. Haworth Press, New York. p. 95-123.

Slafer, G.A., and D.J. Miralles. 1992. Green area duration during the grain filling period of wheat as affected by sowing date, temperature and sink strength. J. Agron. Crop Sci. 168:191-200. doi:10.1111/j.1439037X.1992.tb00998.x

Slafer, G.A., and R. Savin. 1994. Source - sink relationships and grain mass at different positions within the spike in wheat. Field Crops Res. 37:39-49. doi:10.1016/0378-4290(94)90080-9

Slafer, G.A., and R. Savin. 2006. Physiology of crop yield. In: R.E. Goodman and M. Dekkel, editors, Encyclopedia of plant and crop science. Taylor \& Francis Group, New York. p. 1-4.

Slafer, G.A., R. Savin, and V.O. Sadras. 2014. Coarse and fine regulation of wheat yield components in response to genotype and environment. Field Crops Res. 157:71-83. doi:10.1016/j.fcr.2013.12.004

Tollenaar, M., and T.B. Daynard. 1978a. Dry weight, soluble sugar content, and starch content of maize kernels during the early postsilking period. Can. J. Plant Sci. 58:199-206. doi:10.4141/cjps78-029

Tollenaar, M., and T.B. Daynard. 1978b. Kernel growth and development at two positions on the ear of maize (Zea mays). Can. J. Plant Sci. 58:189-197. doi:10.4141/cjps78-028

Tollenaar, M., and T.B. Daynard. 1982. Effect of source-sink ratio on dry matter accumulation and leaf senescence of maize. Can. J. Plant Sci. 62:855-860. doi:10.4141/cjps82-128

Tollenaar, M., L.M. Dwyer, and D.W. Stewart. 1992. Ear and kernel formation in maize hybrids representing three decades of grain yield improvement in Ontario. Crop Sci. 32:432-438. doi:10.2135/cropsci1992.0011183X003200020030x

Ugarte, C., D.F. Calderini, and G.A. Slafer. 2007. Grain weight and grain number responsiveness to preanthesis temperature in wheat, barley and triticale. Field Crops Res. 100:240-248. doi:10.1016/j.fcr.2006.07.010 
Publisher: AGRONOMY; Journal: CROPSCI:Crop Science; Copyright: Will notify... Volume: Will notify...; Issue: Will notify...; Manuscript: crop-2017-11-0676-ora; DOI: ; PII: $<$ txtPII $>$

TOC Head: ; Section Head: ; Article Type: ARTICLE

Vega, C.R., F.H. Andrade, and V.O. Sadras. 2001. Reproductive partitioning and seed set efficiency in soybean, sunflower and maize. Field Crops Res. 72:163-175. doi:10.1016/S0378-4290(01)00172-1

Fig. 1. Top panel: illustration of some steps of the procedure to perform the degraining treatments, firstly carefully opening the husks (left), then - after spraying the ear with $96 \%$ ethanol - removing all grains in rows of alternate rows with a disinfected scalpel (middle), and finally - after spraying the ear with fungicide — closing the husks and keeping them close to their original situation with a loose elastic band (right). Bottom panel: images showing control and degrained ears $15 \mathrm{~d}$ after silking (left) and at maturity (right).

Fig. 2. Left panel: ranges of variation in grains per plant and in average grain weight produced by the combinations of experiments $\times$ hybrids $\times \mathrm{N}$ regimes $\times$ heat during the effective grainfilling period (Table 1) on which the source-sink manipulations were imposed. In the figure, data points belonging to the unheated controls (circles) and to the heat-stressed plots during the effective grain-filling period (HeatedEGF, squares) are identified, and the inset details the overall effect of the heat treatment on the number of grains per plant. Right panel: boxplots for the number of grains per plant across the environments explored (combinations of experiments $x$ hybrids $\times \mathrm{N}$ regimes) for combinations of temperature (unheated controls and HeatedEGF) and source-sink (unmanipulated controls, defoliated, and degrained) treatments.

Fig. 3. Left panel: average grain weight in the defoliated plants plotted against the values corresponding to the nondefoliated control in each of the seven experiments that were unheated (circles) or heated during the effective grain filling period (squares, Exp. 1,3, 6, and 7). The dashed line stands for the 1:1 ratio. The solid line is fitted with linear regression, excluding data points of Exp. 7. Middle panel: boxplots for the loss in grain weight produced by defoliation (i.e., residuals of the 1:1 line) in plants that were unheated or heated (HeatedEGF) during the effective grain-filling period across the environments explored (combinations of hybrids $\times \mathrm{N}$ regimes across experiments in which high temperature treatments were also imposed, and in which grain weight was reduced by defoliation: Exp. 1, 3, and 6). Figures below each of the heat treatments stand for the average and SE of grain weight loss due to defoliation. Right panel: residuals with respect to the regression line (in left panel) averaged for the heat-stressed (HeatedEGF) and unheated plants (segments stand for the SEM).

Fig. 4. Weight of the grains in the basal, central, and apical thirds of the ear (blue, green, and brown symbols, respectively) in the defoliated plants plotted against the values corresponding to the nondefoliated control in each of the seven experiments under heat stress during the effective grain-filling period (HeatedEGF; squares, Exp. 1, 3, 6, and 7) and unheated conditions (circles). Each data-point is the average of all $\mathrm{N}$ fertilization $\times$ hybrids treatments within each experiment. Symbols were closed when the difference with the dashed lines representing $y=x$, the 1:1 ratio, were statistically significant $(P<0.05)$. The bottom right panel summarizes the responses across Exp. 1 to 6 (in which the response was significant). Segments on each bar stand for the SEM, and figures on top of each bar are the grain weights $\left( \pm \mathrm{SE} ; \mathrm{mg}\right.$ grain $\left.^{-1}\right)$.

Fig. 5. Average weight (left) and $\mathrm{N}$ concentration (right) of grains from plants which were either unheated or heat-stressed during the effective grain-filling period (HeatEGF) in factorial 
Publisher: AGRONOMY; Journal: CROPSCI:Crop Science; Copyright: Will notify... Volume: Will notify...; Issue: Will notify...; Manuscript: crop-2017-11-0676-ora; DOI: ; PII: $<$ txtPII $>$

TOC Head: ; Section Head: ; Article Type: ARTICLE

combination with two different source-sink balances: nondefoliated control plants, and defoliated plants (65-75\%) $15 \mathrm{~d}$ after silking. Segments on each bar stand for the SEM.

Fig. 6. Left panel: number of grains per plant in the unmanipulated control plants and in the plants subjected to the degraining treatments under unheated conditions and heat stress during the effective grain-filling period (HeatedEGF), averaged across $\mathrm{N}$ fertilization regimes and experiments. Segments stand for the SEM. Right panel: grain weight of the plants subjected to the whole manipulation required for the degraining but without degraining the ears (placebo) plotted against the weight of the grains in the unmanipulated controls in Exp. 6 (open symbols) and 7 (closed symbols). Each data point is the average of three plants for the placebos and of nine plants in the unmanipulated controls and different data points within experiments belong to the different $\mathrm{N}$ fertilization regimes. Segments on each symbol stand for the SEM. The dashed line represents $y=x$, the $1: 1$ ratio.

Fig. 7. Average grain weight (top panels) or weight of the grains in the basal, central, and apical thirds of the ears (blue, green, and brown symbols, respectively; bottom panels) in the degrained plants plotted against the values corresponding to the controls in each of the two experiments in which this treatment was imposed under no heating (circles) or heating during the effective grain-filling period (HeatedEGF, squares). Dashed lines represent $y=x$, the 1:1 ratio, and all symbols are open, indicating that in none of the cases the difference with the dashed line was statistically significant.

Fig. 8. Average weight (left) and $\mathrm{N}$ concentration (right) of grains from plants that were either unheated or heat-stressed during the effective grain-filling period (Heated $\mathrm{EGF}_{\text {) }}$ in factorial combination with two different source-sink balances: control, not degrained plants, and plants whose ears were degrained $15 \mathrm{~d}$ after silking. Segments on each bar stand for the SEM.

Table 1. Soil characteristics, sowing date, and density of the seven field experiments and treatments ( $N$ fertilization, hybrids, and heat stress during the effective grain-filling period) in each of them that comprise the background characteristics in which the source-sink treatments were imposed. Average daily and mean maximum temperatures during the heat treatment periods (and the proportion of days within that period in which the daily maximum temperature was $>35^{\circ} \mathrm{C}$, shown in parentheses) are also provided In experiments in which there was no heat treatment, the period considered was that from the imposition of the source-sink manipulation to maturity.

Soil characteristics

Temperatur

\begin{tabular}{|c|c|c|c|c|c|c|c|c|c|c|c|c|}
\hline Year & $\begin{array}{c}\text { Exp. } \\
\text { no. }\end{array}$ & $\begin{array}{c}\text { Location } \\
\text { (fields were } \\
\text { close to) }\end{array}$ & $\mathbf{O M} \dagger$ & $\mathrm{N}-\mathrm{NO}_{3}$ & $\mathbf{P}$ & $\begin{array}{c}\text { Sowing } \\
\text { date }\end{array}$ & $\begin{array}{c}\text { Plant } \\
\text { density }\end{array}$ & $\begin{array}{c}\mathbf{N} \\
\text { fertilization } \\
+ \\
\end{array}$ & Hybrid & Heat stress§ & \multicolumn{2}{|c|}{ Average Mean } \\
\hline & & & $\%$ & \multicolumn{2}{|c|}{$-\mathrm{kg} \mathrm{ha}^{-1}-$} & & plants $\mathrm{m}^{-2}$ & & & & - & $\mathrm{C}(\%)-$ \\
\hline 2009 & Exp. 1 & $\begin{array}{l}\text { Algerri (Plain } \\
\text { of Lleida) }\end{array}$ & 1.99 & $175 \#$ & 70.09 & 12 May & 8.03 & No & Lapopi & Unheated & 23.7 & $31.1(1$ \\
\hline & & & & & & & & $\mathrm{N} 200_{6 \mathrm{~L}}$ & PR31N28 & Heat $_{15 \text { DAS-Mat }}$ & 27.7 & $40.2(\mathrm{C}$ \\
\hline 2009 & Exp. 2 & $\begin{array}{l}\text { Seu d'Urgell } \\
\text { (Pyrenees) }\end{array}$ & 1.4 ฯ & $150+\dagger$ & 88.29 & 11 May & 8.50 & No & Lapopi & Unheated & 17.5 & $25.4(0$ \\
\hline 2010 & Exp. 3 & $\begin{array}{l}\text { Algerri (Plain } \\
\text { of Lleida) }\end{array}$ & 1.59 & $141 \#$ & 35.19 & 16 Apr. & 8.40 & $\begin{array}{c}\mathrm{N} 200_{6 \mathrm{~L}} \\
\mathrm{~N} 0\end{array}$ & $\begin{array}{c}\text { PR31N28 } \\
\text { Lapopi }\end{array}$ & Unheated & 23.6 & $30.4(1$ \\
\hline 2010 & Exp. 4 & Algerri (Plain & $1.5 \Phi$ & $141 \#$ & 35.19 & 17 May & 8.40 & $\begin{array}{l}\mathrm{N} 200_{6 \mathrm{~L}} \\
\mathrm{~N} 0\end{array}$ & $\begin{array}{c}\text { PR31N28 } \\
\text { Lapopi }\end{array}$ & $\begin{array}{c}\text { Heat }_{15 \text { DAS-Mat }} \\
\text { Unheated }\end{array}$ & $\begin{array}{l}27.2 \\
21.7\end{array}$ & $\begin{array}{l}39.4(8 \\
28.2(6\end{array}$ \\
\hline
\end{tabular}


Publisher: AGRONOMY; Journal: CROPSCI:Crop Science; Copyright: Will notify...

Volume: Will notify...; Issue: Will notify...; Manuscript: crop-2017-11-0676-ora; DOI: ; PII: $<$ txtPII $>$ of Lleida)

TOC Head: ; Section Head: ; Article Type: ARTICLE

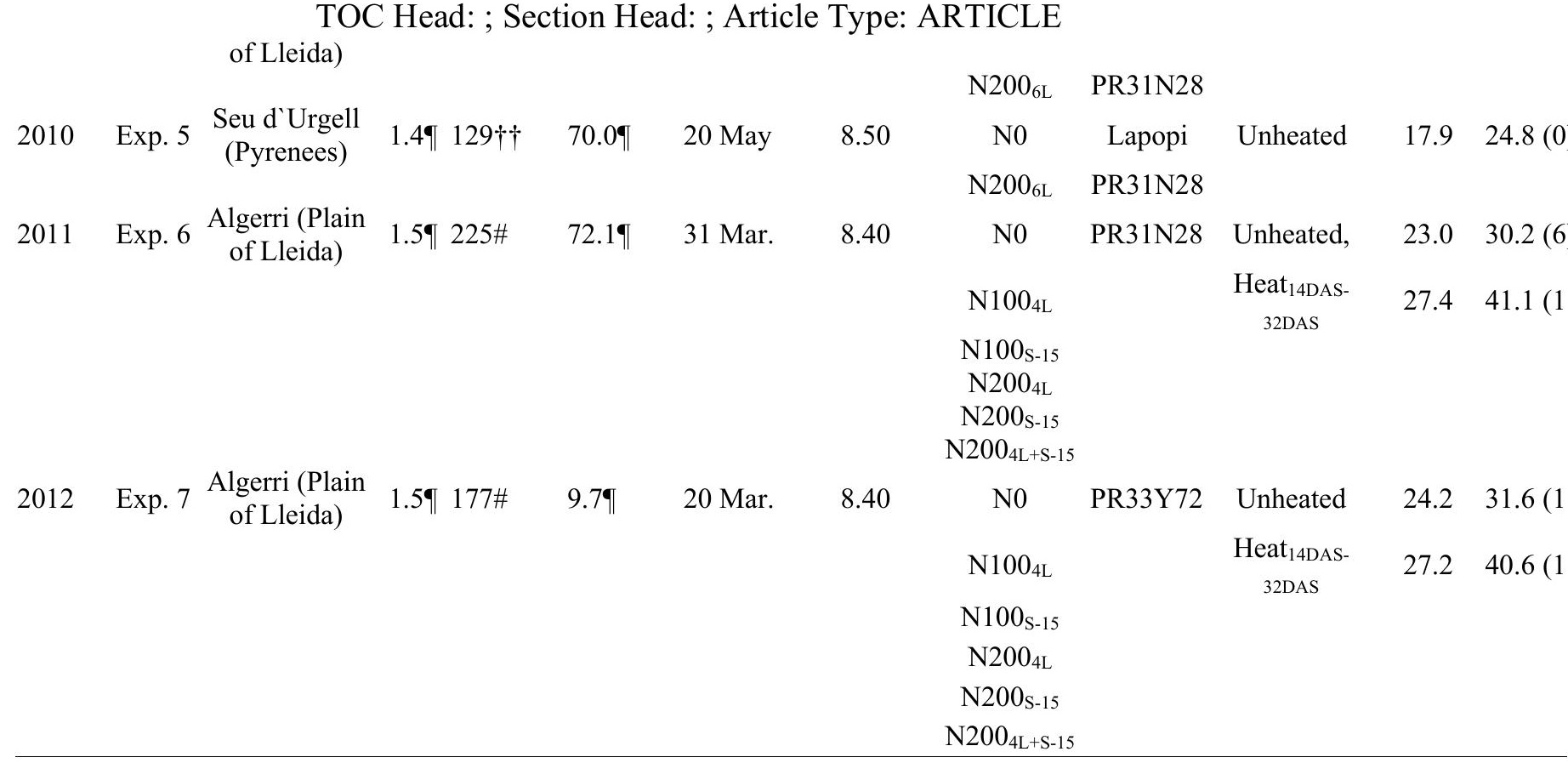

$\dagger$ OM, organic matter.

$\$ 4 \mathrm{~L}, 6 \mathrm{~L}$, and S-15 stand for V4, V6, and 15 d before silking, respectively. 4L+ S-15 means half was applied in V4 and the other half was applied $15 \mathrm{~d}$ before silking.

$\S$ DAS, days after silking; Mat, maturity.

ๆ Top $0.30 \mathrm{~m}$ of soil depth.

\# Top $1 \mathrm{~m}$ of soil depth.

$\dagger$ Top $0.75 \mathrm{~m}$ of soil depth.

Table 2. Outputs of the ANOVA (percentage of total sum of squares, mean square, $F$ ratio, and its probability) restricted to the effects of temperature (control and heat stress [Exp. 1, 3, 6, and 7]), source-sink (control, defoliation [all the experiments], and degraining [Exp. 6-7]), and their interaction (Exp. 1, 3, 6, and 7) on the average weight of the grains within each of the experiments. For all treatments imposed $15 \mathrm{~d}$ after silking, when both temperature and source-sink treatments were combined, the source-sink treatments were subplots within the temperature treatments. The average weight of the grains (across hybrids, when we grew more than one, and $\mathbf{N}$ levels) in the unheated and unmanipulated (for source-sink ratios) controls is also provided (with the corresponding $\mathrm{SE}$ in parentheses).

\begin{tabular}{|c|c|c|c|c|c|c|}
\hline Exp. no. & Source of variation & Total SS $\uparrow$ & Mean square & $F$ value & $\boldsymbol{P}$ & Weight \\
\hline & & $\%$ & mg grain $^{-1}$ & & & mg grain ${ }^{-1}$ \\
\hline \multirow[t]{3}{*}{ Exp. 1} & Temperature (Temp) & 8.6 & 28,567 & 36.5 & $<0.0001$ & $308.9( \pm 9.9)$ \\
\hline & Source-sink (S-S) & 77.1 & 256,643 & 327.7 & $<0.0001$ & \\
\hline & Temp $\times$ S-S & 2.7 & 8,822 & 11.3 & 0.0026 & \\
\hline Exp. 2 & S-S & 93.5 & 160,698 & 963.3 & $<0.0001$ & $319.5( \pm 8.7)$ \\
\hline \multirow[t]{3}{*}{ Exp. 3} & Temp & 31.4 & 44,862 & 99.4 & $<0.0001$ & $231.1( \pm 22.8)$ \\
\hline & S-S & 30.1 & 43,071 & 95.4 & $<0.0001$ & \\
\hline & Temp $\times$ S-S & 0.7 & 958 & 2.1 & 0.1581 & \\
\hline Exp. 4 & $\mathrm{~S}-\mathrm{S}$ & 36.2 & 18,477 & 15.3 & 0.0045 & $229.5( \pm 18.0)$ \\
\hline Exp. 5 & S-S & 75.7 & 52,992 & 342.7 & $<0.0001$ & $270.7( \pm 12.2)$ \\
\hline
\end{tabular}


Publisher: AGRONOMY; Journal: CROPSCI:Crop Science; Copyright: Will notify...

Volume: Will notify...; Issue: Will notify...; Manuscript: crop-2017-11-0676-ora; DOI: ; PII: $<$ txtPII $>$

\begin{tabular}{lclllll}
\multicolumn{6}{c}{ TOC Head: ; Section Head: ; Article Type: ARTICLE } \\
Exp. 6 & Temp & 4.6 & 11,638 & 25.6 & $<0.0001$ & $289.9( \pm 20.9)$ \\
& S-S & 66.1 & 137,013 & 353.2 & $<0.0001$ & \\
& Temp $\times$ S-S & 0.1 & 1,820 & 4.6 & 0.0138 & \\
Exp. 7 & Temp & 30.8 & 42,826 & 139.53 & $<0.0001$ & $278.2( \pm 20.5)$ \\
& S-S & 0.1 & 89 & 0.2 & 0.8649 & \\
& Temp $\times$ S-S & 1.6 & 2,496 & 4.1 & 0.0231 & \\
\hline
\end{tabular}

$\dagger$ SS, sum of squares. 
Publisher: AGRONOMY; Journal: CROPSCI:Crop Science; Copyright: Will notify...

Volume: Will notify...; Issue: Will notify...; Manuscript: crop-2017-11-0676-ora; DOI: ; PII: $<$ txtPII $>$

TOC Head: ; Section Head: ; Article Type: ARTICLE

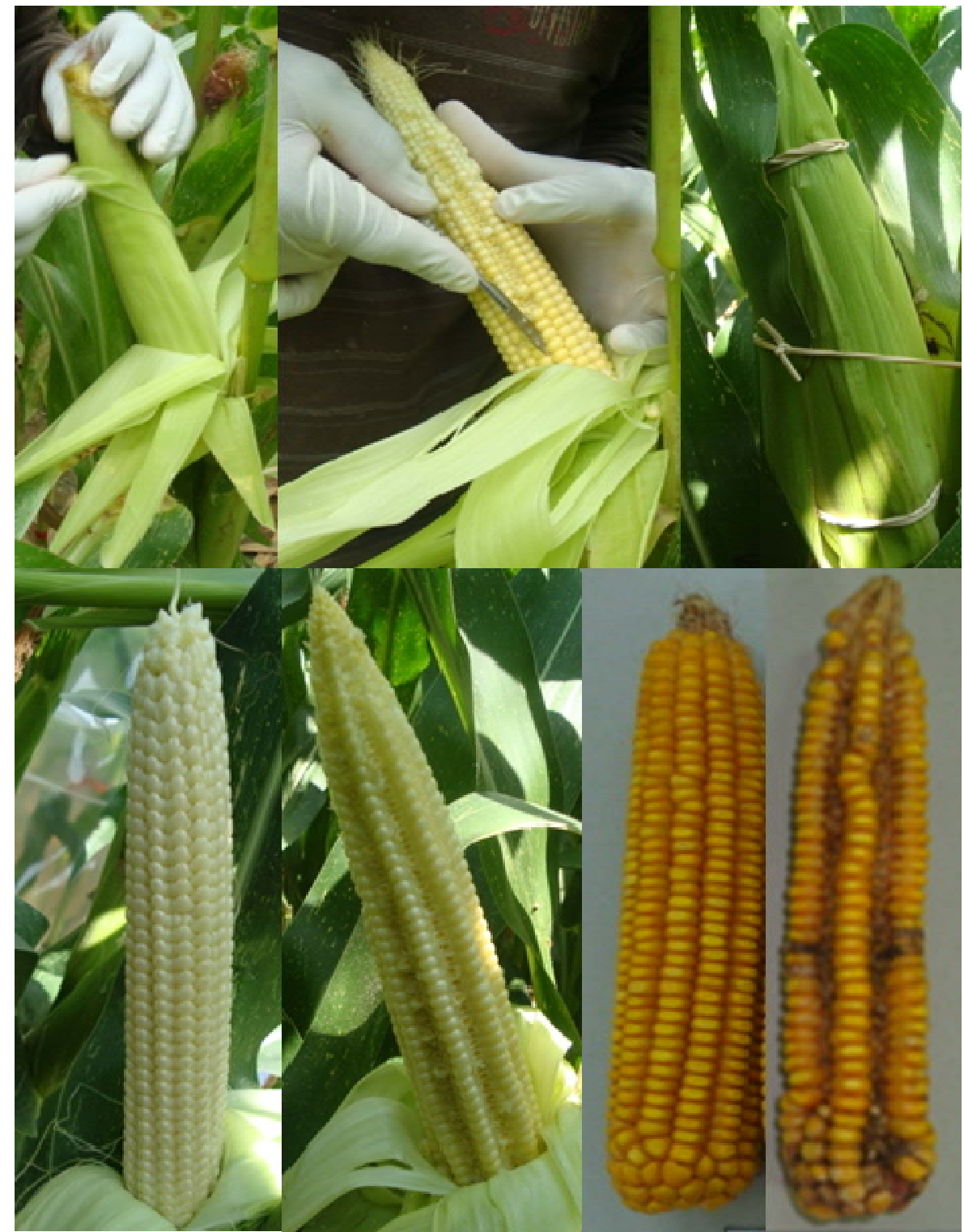

Figure 1. Top panel: illustration of some steps of the procedure to perform the de-graining treatments, firstly carefully opening the husks (left), then -after spraying the ear with ethanol 96\%- removing all grains in rows of alternate rows with a disinfected scalpel (middle), and finally -after spraying the ear with fungicide- closing back the husks and keep them close to the original situation with a loose elastic band (right). Bottom panel: images showing control and degrained ears $15 \mathrm{~d}$ after silking (left) and at maturity (right). 
Publisher: AGRONOMY; Journal: CROPSCI:Crop Science; Copyright: Will notify... Volume: Will notify...; Issue: Will notify...; Manuscript: crop-2017-11-0676-ora; DOI: ; PII: $<$ txtPII $>$

TOC Head: ; Section Head: ; Article Type: ARTICLE
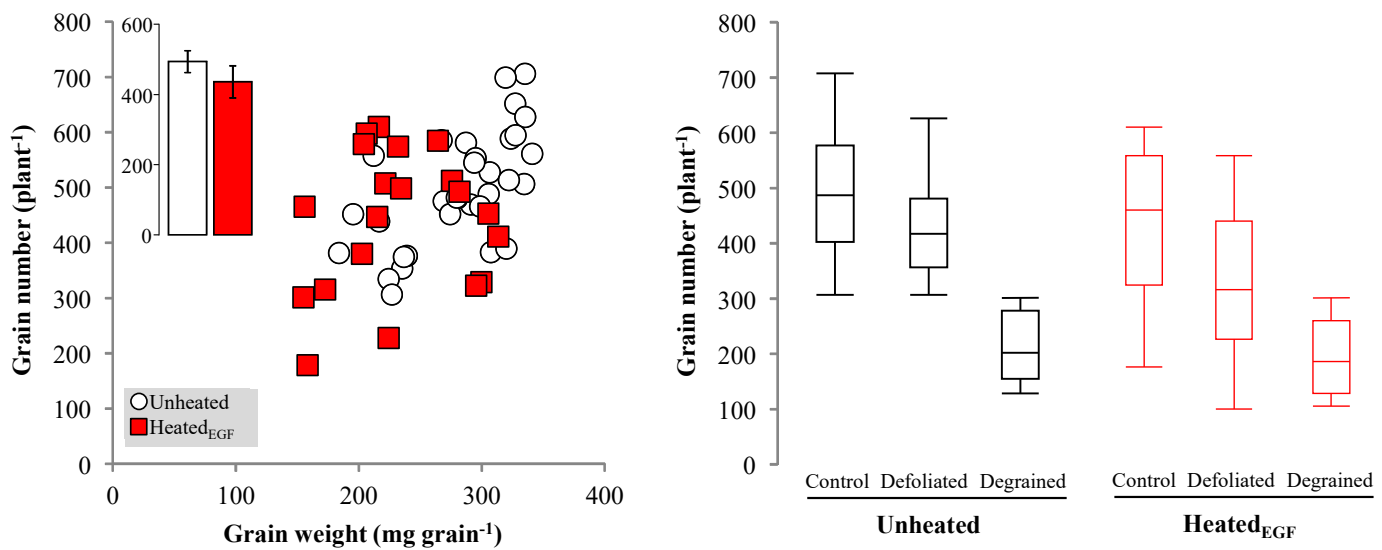

Figure 2. Left panel: ranges of variation in grains per plant and in average grain weight produced by the combinations of experiments $\mathrm{x}$ hybrids $\mathrm{x} \mathrm{N}$ regimes $\mathrm{x}$ heat during the effective period of grain filling (Table 1) on which the source-sink manipulations were imposed. In the figure data-points belonging to the unheated controls (circles) and to the plots heat-stressed

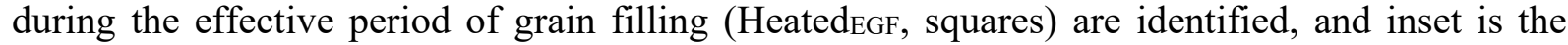
detail of the overall effect of the heat treatment on the number of grains per plant. Right panel: box-plots for the number of grains per plant across the environments explored (combinations of experiments $\mathrm{x}$ hybrids $\mathrm{x} \mathrm{N}$ regimes) for combination of temperature (Unheated controls and HeatedeGF) and source-sink (un-manipulated controls, defoliated and de-grained) treatments. 
Publisher: AGRONOMY; Journal: CROPSCI:Crop Science; Copyright: Will notify...

Volume: Will notify...; Issue: Will notify...; Manuscript: crop-2017-11-0676-ora; DOI: ; PII: $<$ txtPII $>$

TOC Head: ; Section Head: ; Article Type: ARTICLE
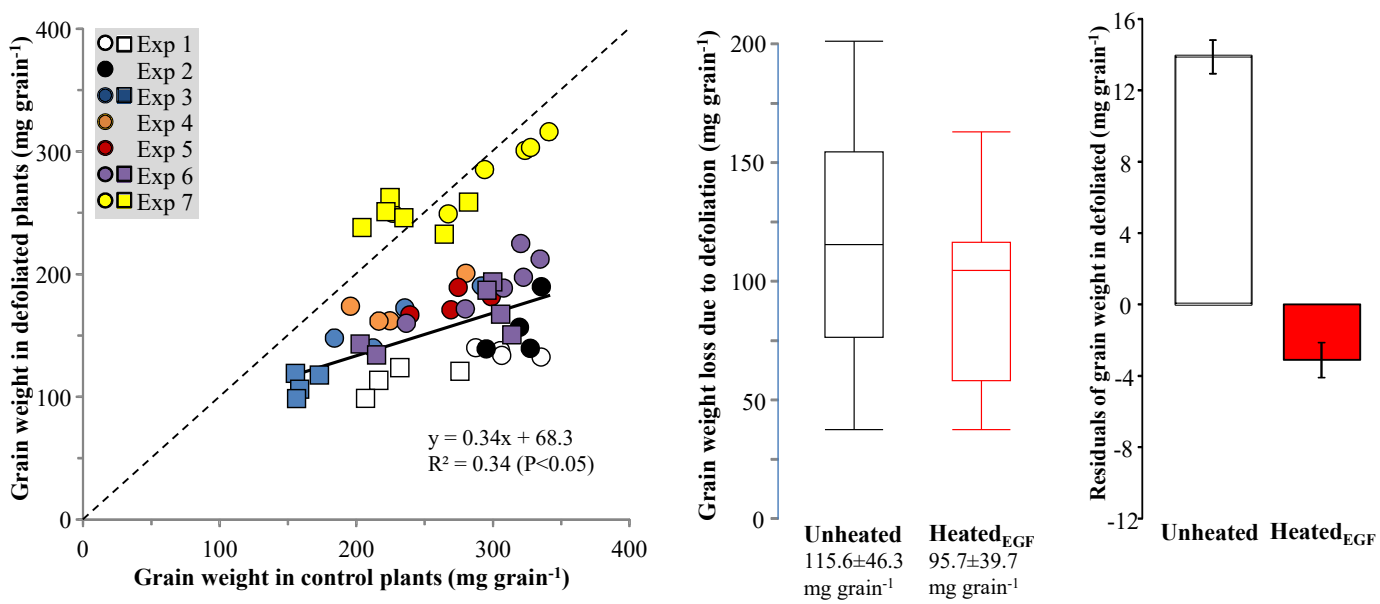

Figure 3. Left panel: average grain weight in the defoliated plants plotted against the values corresponding to the control not defoliated in each of the 7 experiments under unheated (circles) or heated during the effective period of grain filling (squares, exps. 1,3, 6 and 7). Dashed line stands for the 1:1 ratio. Solid line fitted with linear regression, excluding data-points of exp. 7 . Middle panel: box-plots for the loss in grain weight produced by the defoliation (i.e. residuals of the 1:1 line) in plants that were unheated or heated during the period of effective grain filling across the environments explored (combinations of hybrids $\mathrm{x} N$ regimes across experiments in which high temperature treatments were also imposed and in which grain weight was reduced by defoliation: exps. 1, 3, and 6). Figures below each of the heat treatments stand for the average and standard error of grain weight loss due to defoliation. Right panels: residuals respect to the regression line (in left panel) averaged for the heat-stressed and unheated plants (segments stand for the standard error of the means). 
Publisher: AGRONOMY; Journal: CROPSCI:Crop Science; Copyright: Will notify... Volume: Will notify...; Issue: Will notify...; Manuscript: crop-2017-11-0676-ora; DOI: ; PII: $<$ txtPII $>$

TOC Head: ; Section Head: ; Article Type: ARTICLE
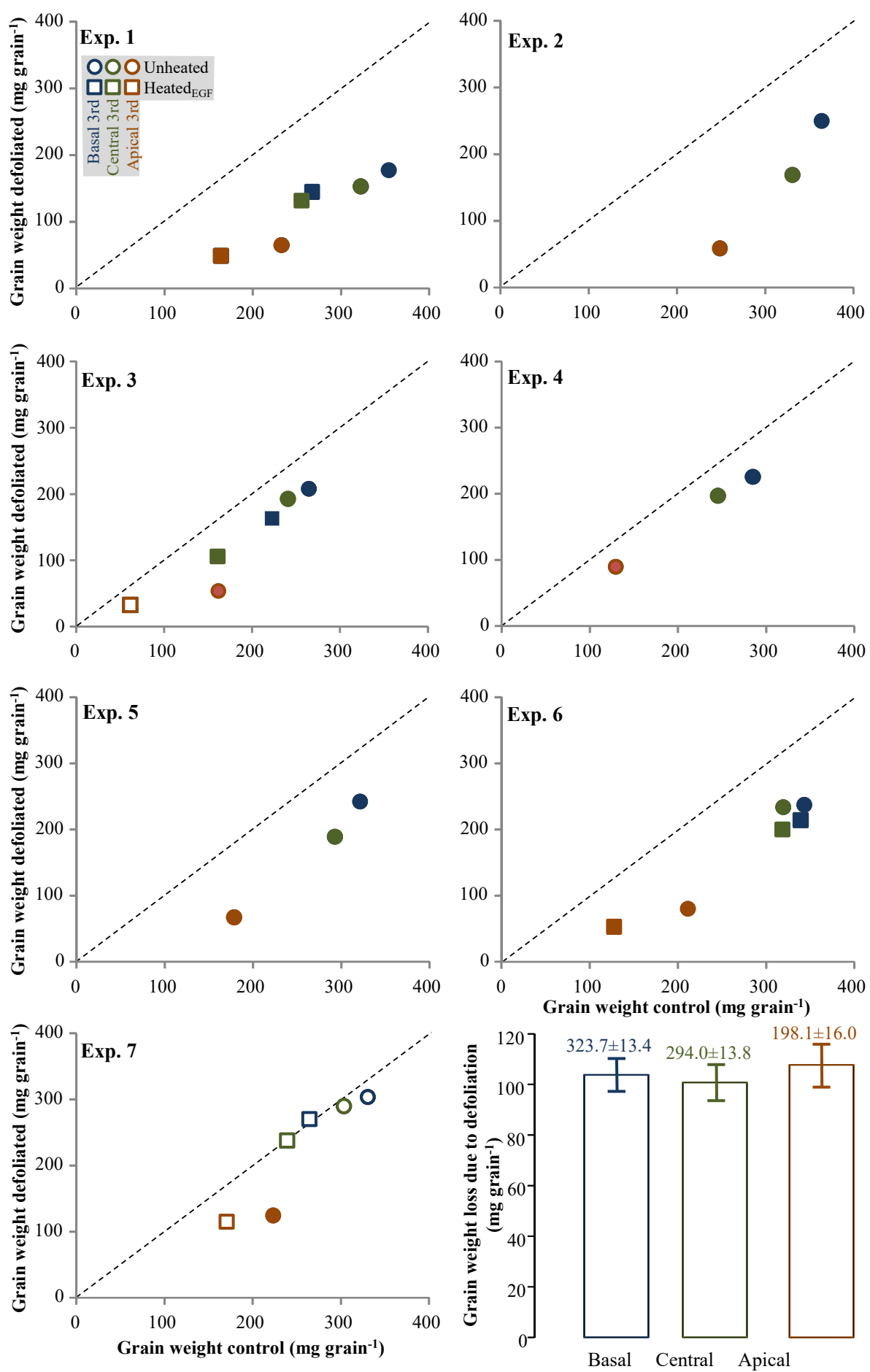

Figure 4. Weight of the grains in the basal, central and apical thirds of the ear (blue, green and brown symbols, respectively) in the defoliated plants plotted against the values corresponding to the control not defoliated in each of the 7 experiments under heat stress during the effective 
Publisher: AGRONOMY; Journal: CROPSCI:Crop Science; Copyright: Will notify...

Volume: Will notify...; Issue: Will notify...; Manuscript: crop-2017-11-0676-ora; DOI: ; PII: $<$ txtPII $>$

TOC Head: ; Section Head: ; Article Type: ARTICLE

period of grain filling (squares, exp. 1, 3, 6 and 7) and unheated conditions (circles). Each datapoint is the average of all $\mathrm{N}$ fertilization $\mathrm{x}$ hybrids treatments within each experiment. Symbols were closed when the difference with the dashed lines representing $\mathrm{y}=\mathrm{x}$, the $1: 1$ ratio, were statistically significant $(\mathrm{P}<0.05)$. The bottom right panel summarises the responses across experiments 1-6 (in which the response was significant). Segments on each bar stand for the standard error of the means, and figures on top of each bar are the grain weights $( \pm$ standard error; 
Publisher: AGRONOMY; Journal: CROPSCI:Crop Science; Copyright: Will notify... Volume: Will notify...; Issue: Will notify...; Manuscript: crop-2017-11-0676-ora; DOI: ; PII: $<$ txtPII $>$

TOC Head: ; Section Head: ; Article Type: ARTICLE
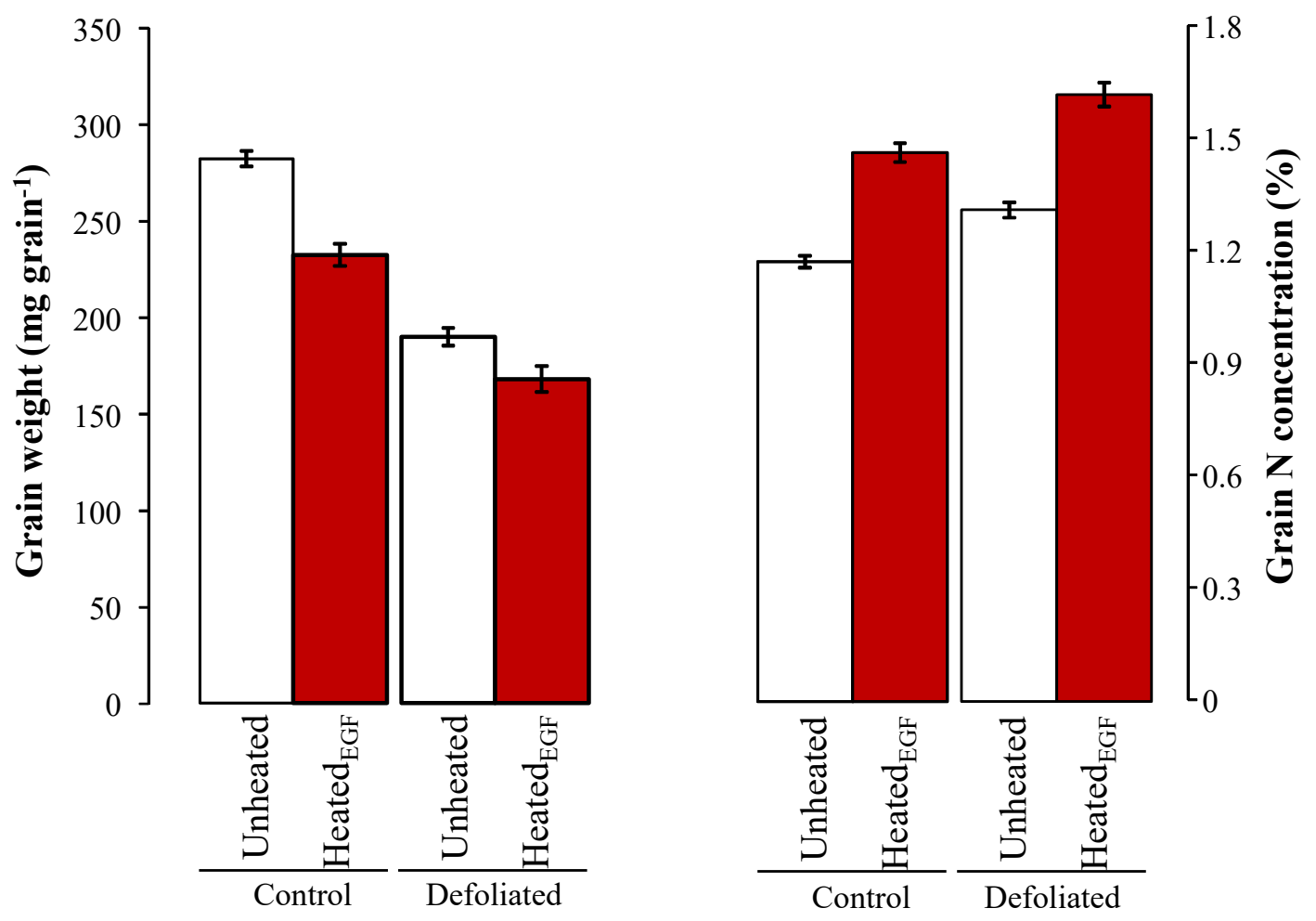

Figure 5. Average weight (left) and $\mathrm{N}$ concentration (right) of grains from plants which were either unheated or heat-stressed during the effective period of grain filling in factorial combination with two different source-sink balances: control, not defoliated plants, and plants defoliated (65-75\%) $15 \mathrm{~d}$ after silking. Segments on each bar stand for the standard error of the means. 
Publisher: AGRONOMY; Journal: CROPSCI:Crop Science; Copyright: Will notify... Volume: Will notify...; Issue: Will notify...; Manuscript: crop-2017-11-0676-ora; DOI: ; PII: $<$ txtPII $>$

TOC Head: ; Section Head: ; Article Type: ARTICLE
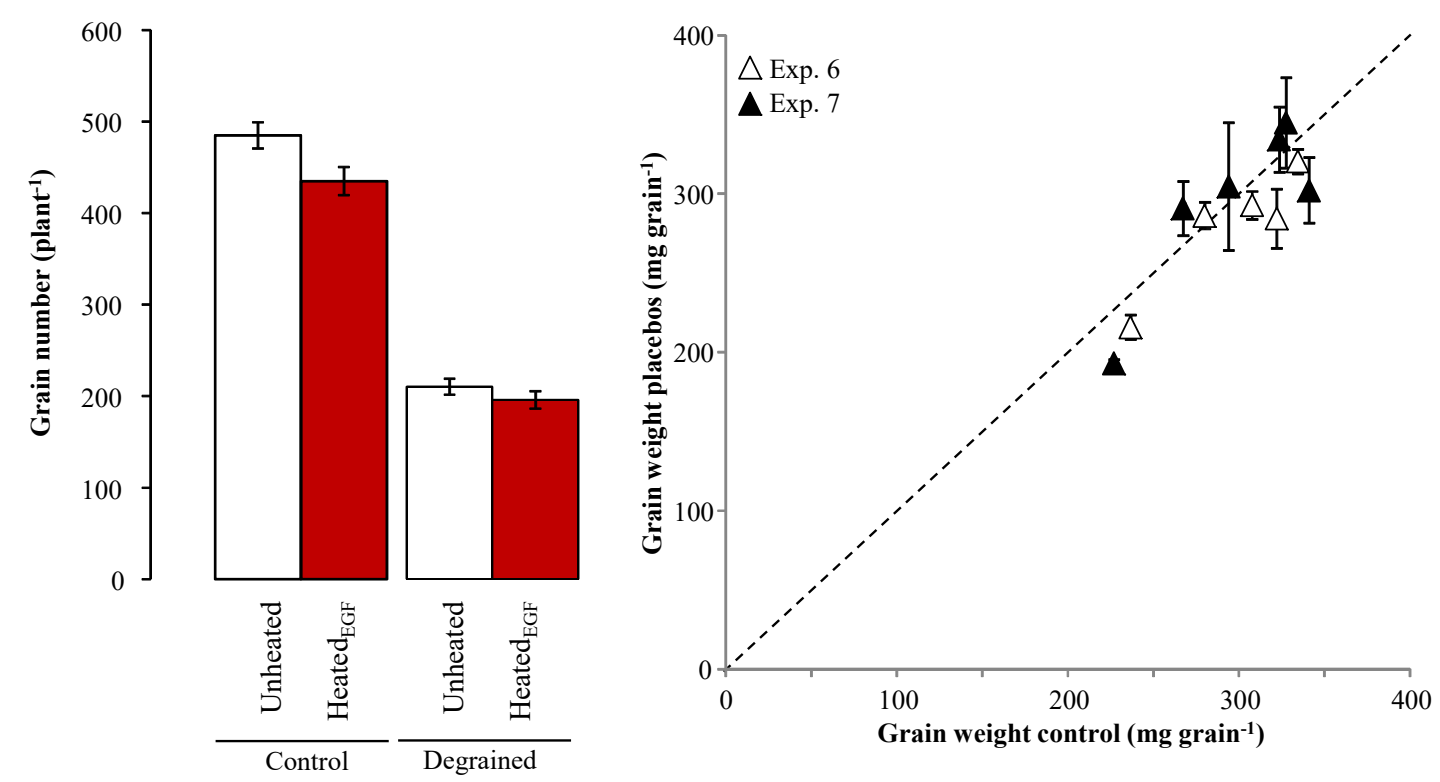

Figure 6. Left panel: number of grains per plant in theun-manipulated control plants and in the plants subjected to the de-graining treatments under unheated conditions and heat-stressed during the effective period of grain filling, averaged across $\mathrm{N}$ fertilization regimes and experiments. Segments stand for the standard error of the means. Right panel: Grain weight of the plants subjected to the whole manipulation required for the de-graining but without de-graining the ears (placebo) plotted against the weight of the grains in the controls un-manipulated in exps. 6 (open symbols) and 7 (closed symbols). Each data-point is the average of 3 plants for the placebos and of 9 plants on the not manipulated control and different data-points within experiments belong to the different $\mathrm{N}$ fertilization regimes. Segments on each symbol stand for the standard error of the means. Dashed line represents $\mathrm{y}=\mathrm{x}$, the $1: 1$ ratio. 
Publisher: AGRONOMY; Journal: CROPSCI:Crop Science; Copyright: Will notify... Volume: Will notify...; Issue: Will notify...; Manuscript: crop-2017-11-0676-ora; DOI: ; PII: $<$ txtPII $>$

TOC Head: ; Section Head: ; Article Type: ARTICLE
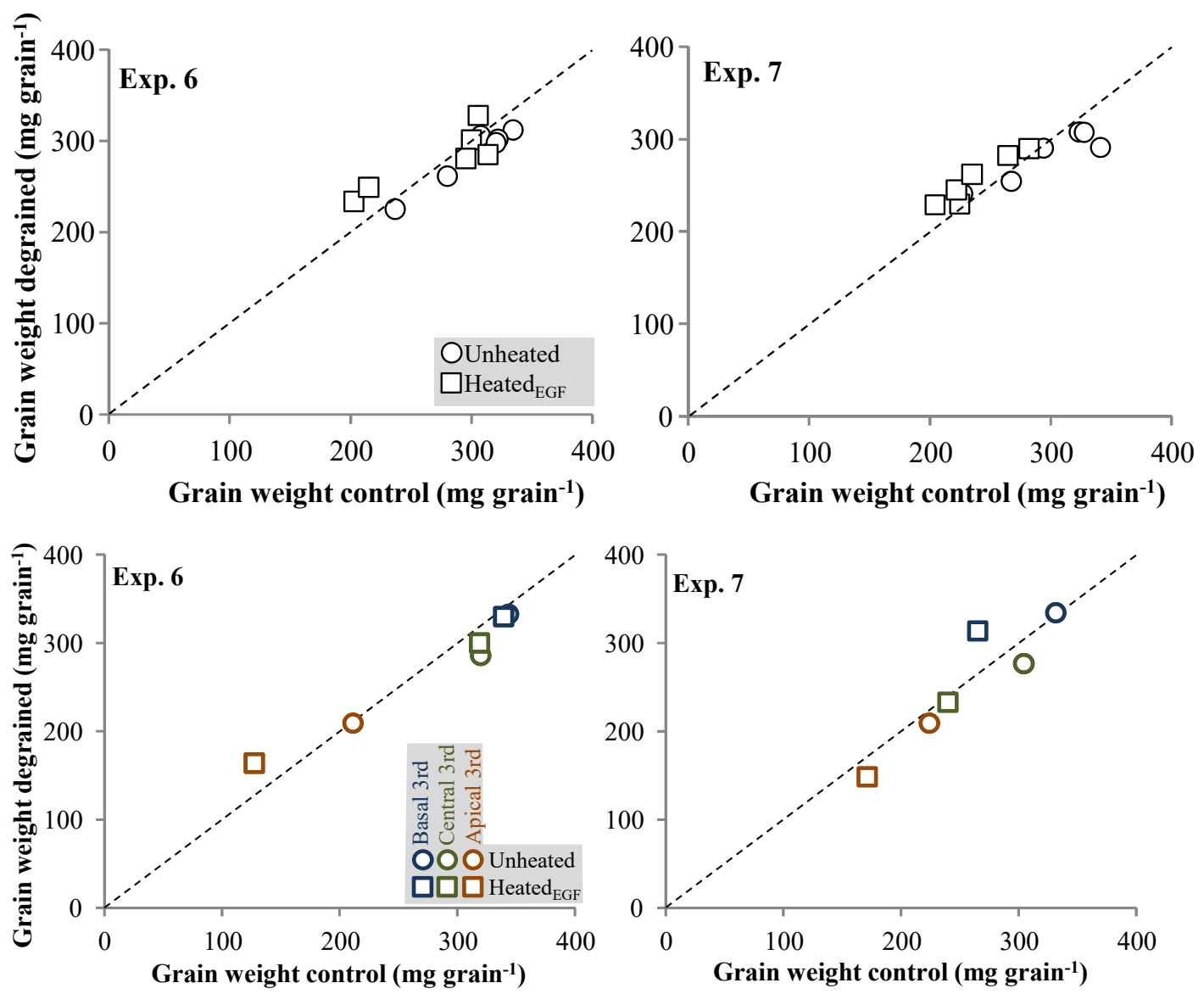

Figure 7. Average grain weight (top panels) or weight of the grains in the basal, central and apical thirds of the ears (blue, green and brown symbols, respectively) (bottom panels) in the degrained plants plotted against the values corresponding to the control in each of the 2 experiments in which this treatment was imposed under unheated (circles) or heated during the effective period of grain-filling (squares). Dashed lines represent $\mathrm{y}=\mathrm{x}$, the 1:1 ratio and all symbols are open, indicating that in none of the cases the difference with the dashed line was statistically significant. 
Publisher: AGRONOMY; Journal: CROPSCI:Crop Science; Copyright: Will notify... Volume: Will notify...; Issue: Will notify...; Manuscript: crop-2017-11-0676-ora; DOI: ; PII: $<$ txtPII $>$

TOC Head: ; Section Head: ; Article Type: ARTICLE
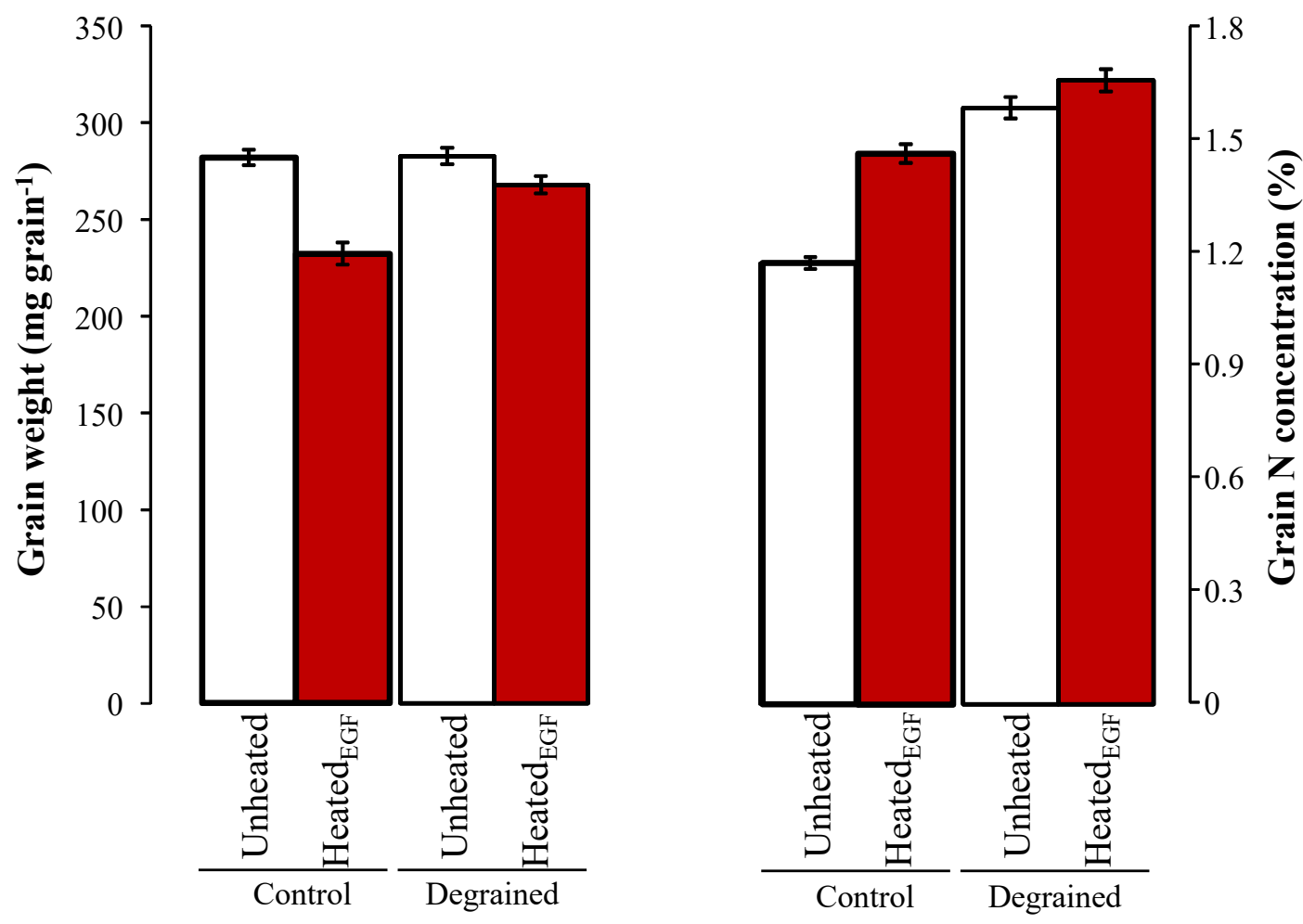

Figure 8. Average weight (left) and $\mathrm{N}$ concentration (right) of grains from plants which were either unheated or heat-stressed during the effective period of grain filling in factorial combination with two different sourcesink balances: control, not de-grained plants and plants whose ears were de-grained $15 \mathrm{~d}$ after silking. Segments on each bar stand for the standard 